University of Louisville

ThinkIR: The University of Louisville's Institutional Repository

Electronic Theses and Dissertations

1939

\title{
A unit of work in folklore for secondary schools with a sampling of Hoosier folklore.
}

Margaret Sweeney

University of Louisville

Follow this and additional works at: https://ir.library.louisville.edu/etd

Part of the American Studies Commons, and the Educational Methods Commons

\section{Recommended Citation}

Sweeney, Margaret, "A unit of work in folklore for secondary schools with a sampling of Hoosier folklore." (1939). Electronic Theses and Dissertations. Paper 1944.

https://doi.org/10.18297/etd/1944

This Master's Thesis is brought to you for free and open access by ThinkIR: The University of Louisville's Institutional Repository. It has been accepted for inclusion in Electronic Theses and Dissertations by an authorized administrator of ThinkIR: The University of Louisville's Institutional Repository. This title appears here courtesy of the author, who has retained all other copyrights. For more information, please contact thinkir@louisville.edu. 
ONIVERSTTY OF LOUISVILLE

A UNIT OF WORK IN FOLKLORE FOR SECONDARY SCHOOLS WITH A SAMPLING OF HOOSIER FOLKLORE

\author{
A Dissortation \\ Submitted to the Faculty \\ of the Graduate School of the University of Loulsville \\ In Partial Pulfillment of the \\ Requirements for the Degree \\ of laster of Arts
}

Department of Education

By

MARGARET SWEENEY

1939 
Name of Student: Margaret Sweeney

Title of Thesis: A Unit of Work on Folklore for

Secondary Schools with a Sampling

of Hoosier Folklore.

Thesis Director: Dr. J. J. Oppenheimer

Approved by a Reading Conmittee Composed of the

Following:

Date: June, 1939 


\section{ACKNOWLEDGMENT}

An undertaking such as the present one cannot be completed without the ald of many persons. To all those who have played a part in this endeavor, I gratefully acknowledge this debt.

To Dr. J. J. Oppenheimer for the development of the unit and the interpretation of its educational significance, 1 am indebted.

To Dr. John R. Broderius for his guidance and help in the fleld of folklore, I am very grateful. His Ideas and suggostions made possible the plans that interested the high school students in carrying out this unit.

To Katherine P. Cain for writing the music scores and for her many valuable contributions of folklore, $\perp$ am deeply grateful.

To Frances Cory for recording the folk songs as sung by the folk for that purpose.

To the teachers of the Jeffersonville High School for their co-operation and assistance in carrying out the unit.

To the students of the junior class of the Jeffersonville High School for their enthusiastic response to the undertaking, and for their faithful performance in its execution.

$$
728
$$


I. INTRODUCTION . . . . . . . . . . . . . 1

II. EDUCATIONAL PHILOSOPHY UNDERIYING THE UNIT • • • 7

1. Changed conception of education. . . . . 7

2. Definition of education.......... 8

3. Functions of the secondary school. . . . 9

4. An explanation of the unit on folklore.. 12

III. THE SETTING OE THE STUDY AND THE TEACHING UNIT • 16

1. The setting of the study . . . . . . 16

2. Origin of the unit............ 17

3. The teaching unit . . . . . . . . . 18

A. Suggestions to the teacher....... 20

B. Outilne for the teacher... . . . . 20

C. Overview. ............... . . 25

D. Objectives for the teacher to present to the pupil. ............ 27

E. Teacher's procedure: . . . . . . 28

a. Approach . . . . . . . . 28

b. Presentation of subject-matter;... $\quad 28$ check-up on information presented

c. Suggestions for pupil activity. . . 29

d. Expected outcomes. . . . . . . 29

F. Correlation with school subjects. . . 30

G. Culminating activitios... ..... . 30

H. Suggestions for evaluating unit . . . 30

I. Bibliography. . . . . . . . . . . 30

a. References for teacher. . . . . 30

b. References for pupil... . . . 31

4. The unit in practice... . . . . . . 32

A. Approach. . . . . . . . . . 32

B. Procedure . . . . . . . . . . . 34

C. Presentation of subject-matteir; check-up on information presented. . . . . . 
PAGE

D. Suggestions for pupil activity. . . . 47

E. Correlation with school subjects. . . 50

F. Generalizations. ... . . . . . 51

G. Culminating activities ... . . . . 54

H. Suggestions for evaluating unit. . . 55

IV. MATERIALS FOR THE TEACHER . . . . . . . . . 57

1. Subject-matter "The Origin of Folklore" . 57

2. Samples of Hoosier Folklore ... . . . . 71

3. Subject-matter "The Folk Tale"...... . 93

4. Samples of Hoosier Folklore ... . . . . 100

5. Subject-matter "The Folk Song". : . . . . 108

6. Samples of Hoosier Folklore . . . . . . 122

7. "Superstitions of the Folk" . . . . . . 139

8. Samples of Hoosier Folklore... . . . . 148

V. CONCLUSIONS. . . . . . . . . . . . . 159

I. Bibliography . . . . . . . . . . 163 
CHAPTER I

A UNIT OF WORK IN FOLKIORE FOR SECONDARY SCHOOLS WITH A SAMPLING OF HOOSIER FOLKIORE

\section{INTRODUCTION}

Denmark has given the world an outstanding piece of work in folk culture and its effect upon a nation. The United States is very much like this little place in its agricultural make-up. The tiny scandinavian country offers a stimulating challenge to the world, as a political democraof which has maintained itself along the lines of its own choosing. And now, when all the world is agog with Hitlers and hussolinis, it is encouraging to look at Grundtvig's plan ${ }^{l}$ for Denmark, when that nation was on the declino. Grundtvig, a tmie democrat, conceived the 1 dea of a folk high school which should break away from classical training and produce "a single unified culture which should be the foundation of a vigorous, creative, national life, to be developed through a system of education, for all the people, based on the national spirit and traditions."

1 A. H. Hollman, The Folk High School (Washington, D. C.: National Home LIbrary Foundation, 1936), p. 136 . 
A curriculum was developed with a two-fold purpose: first, to araken the young to broad outlooks on world history; and second, to dovelop insight into nationel history. The Dane is, today, both a citizen of the world and a national patriot. Hence, the two most common Iines of study omployed are (I) history, as the avallable story of how the race found its way to its present forms of 11 ing; and (2) Iiterature, as the record of the race's most interesting and IIluminating experiences and hopes along the way. History and literature are treated, not as academic materials to be learned, but as doorways and windows into the life of bumanity.

An Englishman who has frequently visited the Danish high schools remarked:

We English have some things to learn from jou $D_{a}$ nes. our history is one of great events but they are not known to the majority of our people. We have also a rich literature but to most of us its existence is unkmown. We should have folk high schools to enable the people to understand their own life and bistory.2

other countries are folk conscious. Dr. Seamus 0.Duilearga, Curator of Irish Folklore Museum and Professor of Irish Literature at the University of Dublin, remarked that Sweden is the authority on the sclence of folklore. He said at a recent meeting of the Hoosier Folklore Society, at Bloomington, that this country offers the best method, technique, and laboratory for those students who wish to

$$
\text { Ib1d., p. } 143
$$


become experts in interpreting the science of folklore. Ireland, since the establishment of the Free state, hes been making a determined offort to collect its folklore, and has been using the schools to help. She is fairly racing with death to save her lore, which is older than any other in the clvilized world.

The United States, the groat melting pot, of fers the most fertile field for the collection and study of the cultures of the world. Much has been done by the various states and by the American Folklore Soclety. Notwithstanding the fact that the latter has celebrated its Golden Jubilee, there are still vast flelis of folklore which remain unexplored. Some states have made valuable advances in this direction, but the country is so rich in material that the surface has just been scratched. The Federal Writers project has alded materially in gathering the folklore of the United States. Indiana, a Midwestern state, is about half agricultural and half industrial in its make-up. It, too, might try an experiment in 1ts high schools similar to the plan used in Denmark. The abundance of its folklore material gives the state a peculiar advantage in such a project.

Such an experiment would begin slowly; the leader must be willing to learn his community before he dares to think of teaching it anything. He must be a learner of the community's ways. He must be able to commend 
Intelilgence to the commanity, above the traditional fear of the comminity that intelligence will undermine the past; above the prejudices of the schoolman that nothing can be called intelligence that is not found in standard books; above the desires of youth to pilo up credits which will "knock the ejes out" of future college officials and prospective employers. The position of intelligence in the world today is almost incredible; it has little standing of its own; it must have records, credits, diplomas for 1ts evidence; and having evidenced itself by these extraneous means, it can then revert to traditional stupidity and "get away with it."3

Such a leader of educational experimentation in Indiane mast be able to in the community and to appeal to the youth of the community by the reality of the thing he offers. Mr. Hart says schools fall in the process of education because they see only one range, Instead of three ranges, of objective. Any truly educative instrument mut help to educate three groups: the pupll, of course; the general public, the community; and the teacher, himself. If the program were carried out, the whole community would forge ahead in intellectual achlevement and the pupils would keep pace with the community.

In such an educational scheme as the development of folklore consciousness in a community, there are several lines of interest which w11l, unfailingly, claim the attention of the citizens, and the pupils as well. Surely there are Hoosier school teachers who can deal with these ines of interest honestly, illuminatingly, inclusively. Some such

(New Joseph K. Hart, Light From the North 
lines of interest, as suggested by the Danish plan, are:

1. How did its communities come to be what they a re? This will be history in terms of the evolution of folkways, customs, and traditions; the gradual development of institutions and their transformations; the growth of social control; the coming of science and the development of social analysis and understanding.

2. The struggles of other communtios, in other times, under other conditions, and the deposit of those struggles in the forms of literature--poetry, history, essay, and in the forms of other arts.

3. The gradual displacement of custom and tradition by means of sclence--in the technics of living and work. The meanings of the displacement for our mind, for our omotions, for our social relationships, for our cultural interests, and for such phases of living as our morality and our religion.

4. The actual structures of our communities; oup traditional economics, our competitivo industries, our varietions in poverty and woalth, our rationalizations of the exigent situations; and the possible development of a more intelilgent community--not by violence, but by honest use of our minds and honest experimentation as in Denmark, with more scientific economics, with cooperative industries, with a more genergl distribution of wealth, with critical facing of all social problems.4

Mr. Hart suggests that the Unitod States will some day find an education more or less after the Danish type, having as its objective, undivided integrity, Individual freedom, undivided creativeness, and individual responsibility--all In a true community situation.

The writer believes her unit of work to be a step toward an appreclation of Indiana's colorful background, its individual community life, its poople, and their culture. She belleves it can be made of practical use to teachers.

$$
4 \text { Ibid., p.. } 155
$$


She hopes to vitalize the teaching of English by stimulating the pupil's interest in himself, his ancestors, and his own environment; to help him take his place in 1ife, to give him sense of the interdependence of people by teaching him how his culture was made. For example, when he realizes that place names show a development of language and history, he becomes interested in other word origins, which interest leads him on in apirit of investigation, and encoursges $\mathrm{h} / \mathrm{m}$ in a better understanding and appreclation of his own language. From the study of folklore, he gets an insight into how literature began and how it has developed. From the inadequacies of the folk, he learns to have a greater respect for correct usage in both oral and written composition. He learns, too, that though untaught, the folk had an art in form and expression which literary people have tried to Imltate. Ho discovers how his own personal history, his community's history, and that of the world at large are tied up with the lore which he found in his own locality. 
CHAPTER II

EDUCATIONAL PHILOSOPHY UNDERLYING THE UNIT

OF WORK IN FOLKLORE FOR SECONDARY SCHOOLS

WITH A SAMPLING OF HOOSIER FOLKLORE

Changed Conception of Education. The aim of -ducation today is to direct intelligently and give meaning to those activities of the pupil which function in life--the ilfe of which he is to become part, and for which he $1 \mathrm{~s}$ being educated. Changes in social conditions and institutions affect the details of educational objectives; therefore, these issues must be met with a knowledge of the attitudes of youth, his problems, and his capacitios. One of the important aims of the early American high school was preparation for college. This aim dominatod all curriculum materials, and the high school course was a bookstudy course, designed to satisfy this purpose. As groups, made up of persons who did not have college as their objective in education, Invaded the secondary schools in over increasing numbers, new alms and new procedures became impera-. tive.

Dewey has sketched the change which life in the United States has undergone, demanding great educational modification by enumerating the following: 
1. Over one hundred years ago our life was agrarian and rural. During the nineties of the last century our society became definitely urban and industrial.

2. There has boen a revolution in the method by which things get done.

3. We have altered from a population with simple political problems to one with extremely difficult and complex 1s sues.

4. Control of natural forces by means of machinery has brought to humanity the possibility of an amount of lelsure from which the mas of men and women in the pest were hopelossly shut out.1

The school of yesterday kept itself aloof from social realities. Today the rapidity of change demands that the school shall keep in close touch with sociel processes. Democracy requires that the school discover the means by which to roostablish that equality of opportunity which is the dream of a free nation.

Workers in secondary education must realize that they, as individuels, are helpless; they noed the stimulus of public opinion to bring about the most effective training of youth for the needs of the day, as well as to provide for curriculum reorganization.

Definition of Education. Education is a continuous process of worth-while experiences which fits the individual In this changing world, to live abundantly and to serve soclety to the maximum degree. This process of adjustment is

\footnotetext{
John Dewey, "Some Aspects of Modern Education" School and Society XXIV (October 1931) p. 582
} 
one in which the individual not only is affected by his environment, but also is capable of changing or creating the situation in which he lives.

Function of the Secondary School. The Department of Secondary-School Principals of the National Education Assoclation ${ }^{2}$ gives the functions of secondary education as follows: (Irrelevant functions omitted.)

Function $I$

To continue by a definite program, though in a diminishing degree, the integretion of students. This should be on an increasingly intellectual level until the desired comon knowledge, appreciations, ideals, attitudes, and practices are firmiy fixed.

Function II

To satisfy the important immediate and probable future needs of the students in so far as the maturity of the learner permits, guiding the behavior of youth in the light of increasingly remote, but always clearly percelved and appreciated, social and personal values.

Function III

To reveal higher activities of an increasingly differentiated type in the major fields of the racial heritage of experience and culture, their significant values for social living, the problems in them of contemporary iffe, the privileges and duties of each person as an individual and also as a member of social groups; to make these fields satisfying and desired by those gifted for successful achievement and to give information as to requirements for success in these flelds and information as to where further training may be secured.

\footnotetext{
2 Thomas H. Briggs, Functions of Secondary Education (Washington, D. C.: National Educational Association Bullet in of the Department of Secondary-School Principals), pp. 5-8
} 
Function $\mathrm{V}$

To systematize knowledge previously acquired or being acquired in courses in such ways as to show the significance both of this knowledge, and especialit of lave and principles, with understanding of wider ranges of application than would otherwise be percolved.

Function VI

To establish and to develop interests in the major fields of human activity as means of happiness, to social progress, and to continued growth.

Function VIII

To use in all courses as largely as possible methods that demand independent thought, involve the elementary principles of research, and provide intelligent and somewhat self-directed practice, Individual and cooperative, in the apropriate desirabie activities of the educated person..

Mr. Briggs, as chairman of the Committee on the Orientation of Secondary Education Department of Secondary School Principals, points out these facts: The functions as stated are not all the peculiar responsibility of secondery schools. Several may, in varying degrees, begin in the elementary school and continue at loast through the funior college. The comittee believes, however, that each one Iisted is important in the education that normally begins about the age of twelve and concludes some six or elght years later. Reiterating its belief that education should be a "gradual, continuous, unitary process," the committee recognizes that, for practical purposes of administration, an educational system w11l be divided into units of organization; and it main- 
tains that such units can be logically made only on the basis of clearly recognized functions that a peculiar, or at least of peculiar emphasis, for each division. One value, then, of agreement on the special functions of periods of education, is to onable us to decide logically what the administrative units should be.

A second value of the stated functions is to stimalate the profession to clarify its philosophy of secondary education.

A third value of the stated functions is, when they are understood and approved, with such modifications as may seem wise, to furnish criteria by which the program of any school may be evaluatod.

Another value of agreement on the special functions of secondary education is that they will give direction to the formation of new programs of organization, of administration, and of curriculum construction.

The final value of agreement on the functions of special emphasis in any administrative unit is that it makes possible the preparation of a program of articulation.

The writer finds it encouraging to note that the philosophy in her unit on folklore colncides with that offered by leaders in the field of secondary education. This is expressed particularly in "Function III" in regard to acquainting young people with their cultural heritage, and in attempting to roveal opportunities for activity in the hitherto unknown field of their own heritage of experience and culture. 
Educators now realize that to give to the present school population, made up of all sorts of pupils, some 1dea and appreciation of the finer opportunities afforded by specified study is a problem at once difficult and acute. Interpreting these activities to the pupil, the school need not consider itself the sole educational agency nor the only means by which the pupil is lead to find in home, community, and all areas of his environment, opportunfties for activity which the school cannot directly provide. Church, home, social and civic institutions all share this responsibility. An Explanation of the Unit on Folklore. For the past two decades there has beon a gradual acceptance of the term "unit." It is a direct outgrowth of the project idea and a reaction against the fragmentary nature of lesson learning. Mr. Harap interprets the unit to be a complete and coherent loarning experience having a purpose which is meaningful to the pupil, accepted as his own, and which is closely related to a life situation. If the whole of the curriculum consists of a balanced sequence of meaningful situations, all the necessary fundamental processes will oporate functionally, because the most useful ones will recur in the successive learning units. Learning goes on most effectively when a child onjoys and feols at home with what he is doing as he works under the intelifgent guidence of his teacher. Mr. Harap's Comittee on Curriculum sets up the following criteria: 
1. Has the problem arisen because of particular interests, questions, needs, or experiences of the children in the group? (Varlous situations may be provided by the teacher to stimulate such interests.)

2. Is the study appropriate for the maturity level of the group being cons1dered?

3. Does this problem provido possibilitios for challenging the child's thought (and action when possible) to the extent that experionces become a necessary and integral part of the child's daily living?

4. Is it possible to provide materials and trips which are necessary for this study?

If a unit fulfills these criteria it will be a socializing influence as well as an influence toward wholes ome personal integration which is the greatest purpose of education. 3

Before attempt ing to write a unit of work on folklore, the writer made a study of the subject under Dr. John Broderius, at the University of Loulsvilie. From the course taken, from her experience as a teacher of English in high school, and from a collection of folk material gathered throughout Indiana, she has built a unit of work for the junior year of senior high school. The untt has been constructed so that the pupil will enjoy his study while he is gaining knowledge about his own traditions.

The language arts, abilities, and skills are essential to growth and progress in all subjects. The conscientious toacher of these language arts will realize that her

3 Henry Harap, An Experience Curriculum

National Council of EngIish Teachers, Washington, D. C., pp. 109-110 
task 1s one of inter-relation; she must serve the whole school. She is teaching a tool subject; therefore, she mat help her pupils to get neoded experiences through an integration of all their school activities.

This unit of work on folklore is organized around a vital center of interest: the student, his ancestors, his community. It is the responsibility of the teacher to provide learning situations through which the child may be encouraged to express himself offectively, clearly, and correctly in connection with his particular project or activity.

Since the real education of the child must be based upon objectives in child growth; since it must be challenging to the child, and must rocognize a vital part of his iffe; Ance it mast include physical and intellectual experiences; since it mast provide opportunities in acquiring information, skills, and behavior or thinking; the teaching content in this work on folklore has been organized on the unit plan. The unit, which is not work shoots but means of loarning and doing, is mado up of combinations of subject matter, child experience, and pupil learning. The fusion of folklore, literature, and composition (oral and written) demands knowledge of, and creates a need for, correct usage, and thus the real function of grammar is recognized. Folklore and literature supply the subject matter around which 
the child's experiences rotate; grammar is taught in a functional way, for its chief purpose is the correct expression of thought. The unit found in this study has been constructed in a flexible way, around the general gulding principle set up by Mr. Harap.

The writer belleves that her unit on folklore integrates study and other experiences; that it meets the requirements stated above because it is a study of the child's environment, his ancestors, and their traditions; it is well balanced because it is integrated with ifterature and life; it is orderly because it is explained in a sequence of units, and the writer believes that students are well guided because they are bringing in the lore, classifying, and interpreting it, according to her expectation. They are integrating the school, the home, the community, and their own cultural heritage, in a new and broader perspective. They are developing cumulative techniques in both written and oral composition by learning to express themselves well as they meet people and interview them, and record their findings. Some students typed the contributions to this record for the school library. In the book they have assembled the tales, songs, and superstitions which they have found in their community. Several students 
have drawn maps of Indiana, locating the place names whose origins other members of the class have found. Some heve taken pictures of the places and people. There are so many possibilities for growth and development in the unit that the writer feels it meets the criteria for a good unit of work. 


\section{CHAPTER III}

SETTING OF THE STUDY AND THE TEACHING UNIT

Setting of the Study. Jeffersonville High School is situated on the corner of Melgs and Court Avenues in the city of Jeffersonville, Indiana. A clty of the fourth class, Jeffersonville is bounded on the south by the Ohio River and Louisville, Kentucky; on the wost by Clarksville and New Albany; on the north by 1ts townsh1p; and on the east by Utica. Jeffersonvilie, founded in 1802 , is one of the oldest river towns in the state. When she celebrated her centennial, her sophisticated neighbors remarked, "She doesn't look her age." More than a quarter of a century has not improved her financial status; however, Jeffersonville folk love thoir river home and treasure the traditions, customs, and bellefs which are their cultural heritage.

Not only is the nelghborhood environment rich in folklore, but Jeffersonville High School affords unusual opportunities for its study. The teachers have freedom of opportunity for innovations, and for developing new 1deas. The curriculum which is offered by the state course of study is merely suggestive and does not restrict the teacher in her experimentation. She is free to adapt it to each or any particular group of children in harmony with their interests, needs, and abilities. Experiences may be integrated through 
their organization around a unifying interest. Trips are made possible and encouraged by the generous co-operation of parents who lend their cars for such excursions.

The school is not equipped with a well-chosen library, but this need has been met by help from the Indiane state Lending Library and the Jeffersonville Township Library. (The latter is gradually being rehabilitated after the ravages of the 1937 ohio River flood.)

The Junior-Sentor High Sehool has an enrollment of about twelve hundred students. The classes average approximately thirty students, usually containing a nearly equal division of boys and girls.

The pupils of the school are of average mental abllity. There is a very democratic social atmosphere in the school, which is carried over to the home. The parents are interested, but not aggressively so.

\section{Origin of the Unit. The writer of this experiment} is a teacher of English in the Jeffersonville High School. During the school year of 1938, Robert Allen, in the English Department of Indiana University, asked her to help organize a Hoosior Folklore Soclety. Invitations were sent to English teachers throughout the state, and the new society was founded at Indianapolis in October of that year. The members were urged to collect the folklore of Indlana, which was 
rapidis disappearing. At this time the writer was studying contemporary drama under Dr. David Maurer at the University of Loulsville and was searching for Hoosier folk plays. During this invostigation, she unearthed very little drama, but had success in socuring other types of folklore. Dr. Maurer then directed her survey of the field. The idea occurred to her that this problem of collecting folk tales, songs, superstitions, and the like, would be an interesting one for the students in her English olasses. She then planned to give them a glimpse into the field of folklore, introducing them to its rich and varied content. If 11 terature is life, so then is folklore. It had its beginnings in remote primitive days; yet it is alive today all over the earth. In 1ts study, the students are taken away from mere subject matter and led to a broader culture, as they get the experience of collecting their lore from grandmothers, neighbors, and friends in their commity. They are led to find a real purpose in their oral and written English work; to learn how to meet poople; to learn patience, perseverance, and accuracy; and to take pride in their own heritage as they try to make a worth-while contribution of interesting Hoosier tradition to the general acumen. 
THE

TEACHIN G UNIT 
THE TEACHING UNIT

Suggestions to the Teacher. The teacher mat know her subject matter. She mast familiarize herself with all avaliable materialsi in connection with the folklore of the community. She must bo very definite in her own mind as to the objectives she hopes to achleve. A clear reference outline and a broad overview of the entire unit will provide her with the necessary knowledge of its scope. She must herself be a worker in the field of research. It is not necessary that she have expert knowledge of the sclence of folklore, but she must have an understanding and appreciation of the folk through personal contact.

Outline for the Teacher.

I. The orieln of folklore:

A. Folkionists say origins are primitive man's explanation of natural phenomena.

Read: F1ske, John, Myths and Mythmakers, Chapters I and $V$

Baring-Gould, S., Gurlous Myths of the Middle Ages

1. Examples of nature myths

a. Sisyphos, a myth about the sun.

Read: Sábin, F. E., Classical Myths That Live

b. Cattle of the Sun, a myth about the sun.

Read: Homer, The odysser, Translation.

1 Books on this subject are often not avallable in school and local librarios. Large cities or university towns may provide some of them. Mny may be borrowed or rented from other city or state libraries. The University Press, Chapel H111, North Carolina, has perhaps the most complote rental folk library. 
c. Jack and the Bean Stalk represonts in a flgure the $w$ ind, the rain, and the sun restoring the means of Iffe to the crops.

Read: Encyclopedia Americana, vol. 15, p. 546.

d. William Tell is a nature myth.

$R_{e}$ ad: Baring-Gould, S., Gurious Myths of the Midàle Ages

B. Anthropologists say primitive man makes up stories about persons and places.

Read: Tylor, E. B., Primitive Culture

Tylor, E. B., Anthropology

1. Examples of myths and legends about persons and places.

Q. Tup1 and Guaran1--tribe names.

b. Brutus and Corineus account for the names of Brita in and Cornwall.

c. Blue Beard, an historical person, Giles de Retz, Sleur de Laval, Marshal of France, nicknamed Barbe Bleu from having a beard of blue-black shade.

Put together from many sources, historical as woll as mythical.

2. Examples of myths and legends about fossil bones. a. Giants and their bones--Haokah.

3. Examples of myths and legends from dreams. a. Primitive man belleved in dreams and in the spirit world--the existence of a spirit or soul as distinct from matter--the bellef in inanimate objects as possessing personal iffe or soul--this principle is calied animism. Read: Tylor, E. B., Anthropology

$$
\text { Fiske, John, Myths and Hy thmakers }
$$

b. Examples--note various systems of spirits and deities in barbaric and ancient religions.

(I) Buddha as a bird.

(2) Ojibwas pictured the souls of their dead leaders laden with gifts on their journey to spirit land.

(3) Germans put shoes on feet of corpse, the "holl-shoon" 1th which old Northmen were provided for the dread journey.

(4) The Irish place a coln in the hand of the corpse in order that it may be able to pay its way into the other world. 
II. The folk tale.

A. Origin.

Read: Hartland, E. S., The Sclence of Fairy Tales Cox George W.' An Introcuction to the Sclences of Comparative 4 ythology

1. Kinds of folk tales. Sagas are looked upon as stories of actual occurrencos.

a. The Story of King Arthur.

b. Rip Van Winkle.

Marchen or nursery tales, told for amusement

a. Puss in Boots

b. Cinderella

B. Science of the folk tale.

Read: Hartland, E. S., The Sclence of Falry Tales Grimm, Jácob and WITheIn, BIogTa pnies

1. Grimm brothers were first to make a comparative study of the folk tale.

a. They collected old tales from old dames and nurses in Germany and other countries.

b. They discovered striking similarity in certain plots, incidents, and basic elements.

c. From their Iindings the Grimms worked out a comparative mythology.

2. National characteristics of the folk talo. Read: Leo, F. H., Folk Tales of All Nations

a. Arablan tales in the original were coarse romantic, elaborate, elegant--Arabian Nights Entertainment.

b. Talos from India are older than any other tales. The Panchatantra dates as far back as $200 \mathrm{~B}$. C. They a re fentastic, full of superstition, gorgeous, precocious, abundant.

c. The English tales are qua int, humorous, simple, and pleasing in their setting. Their fairies are assembled in a clan and are lively spirits and mischievous olves.

d. The Scottish tales are serious and romantic and lack the humorous twist found in both the English and Irish stories.

- The Irish tales have kept the old World touch. They are supernatural and rejoice in the presence of spirits-the "good people" whose rights they never fall to respect. There is a great deal of humor and pathos, too, in their tales. 
f. The French tales do not ring quite so true to Iffe as do the English. They present the ball room, the court--the simple life is not there, but rather a romantic mockery.

8. The Spanish tales aro in substance very much like other European storles.

III. Folk song and ballad.

A. Origin.

Read: Auslander, Joseph and Hill, Frank Ernest, The Winged Horse

Gerould Gordon Hall, The Ballad of Tradition Boggs, Ralph Steole, FOLKIOTE

Pound, Loulse, American Ballads and Songs

Gummere, F. B., Folk Song

1. Communal theory.

2. Gifted Individual, poet in the group.

B. Themes.

1. Sex.

2. Love.

3. Family relations.

4. Fights.

5. Adventures of the sea, the forest, the mountains, etc.

6. Tricks and riddies.

7. Superstitions.

8. Now Testament miracles.

9. War.

C. Where they are.

1. Isolated places.

2. Mount ains in Southeast and Western ranches.

3. Among the negroes in the South.

4. $A_{m}$ ong the Spanish in New Mexico.

D. Distinctions between ballad and folk song.

1. Ballad

a. Objective

b. Impersonal

c. Words important

d. Story important

- Epic of the folk

f. Dispute over origin -
Folk song

$S_{\text {ub jective }}$

Pers onal

Words meaningless

Mus 1c important

Lyric of the folk

Not so mucr dispute over origin

Both have provoked literary imitations, are oral, in a state of change, and live through a fair period of time. 
E. Collectors and Authorities.

1. James Francis Child.

2. Sir Walter Scott.

3. Sevund Grundtvig.

4. George Lyman Kittredge.

5. Loulse Pound.

6. Francis B. Cummere.

7. John and Alan Lomax.

8. Gordon Hall Gerould.

IV. Superstitions of the folk.

A. Origin.

Read: Frazer, J. G., The Golden Bough

Clelo,'Astra,'s igns, Umens gra Superstitions

Thomes, Daniel Lindse Kentuck Y Superstitions Boggs, Ralph Steole, FolkLor

Kittredge, George Lyman, WItcheraft in old New England

B. National and racial beliefs in fairles and witches.

1. Hindoos believe in Acvins.

2. Persians in Peris.

3. Arablans in Jinns.

4. Jews in Shedin.

5. Grooks and Romans in dryads, nalads, fairles, and satyrs.

6. Italians in Fata Morgana.

7. French in follets, foes, lukins, and goblins.

8. Scandinavians in playfui and maliclous elves and trolls.

9. Teutonic races in falries, trolls, gnomes, and dwarves.

10. Irish in fairies and all sorts of little people.

11. Scotch in brownies.

12. English in individual spirits and clans of fairies.

C. The common superstitions.

1. Those about Friday.

2. The number thirteen.

3. The dropping of a knife, a fork, or a spoon.

4. The picking up of a pin.

5. The first sight of the new moon.

6. The breaking of a mirror.

7. The presenting of a knife to a friend.

8. The potency of the horseshoe.

9. The burning of the ear.

10. The passing of two companions on the opposite sides of $a$ post.

11. The howl of a dog.

12. The presence of a bird in the house. 
13. The opening of an umbrella in the house.

14. The turning back after one has started.

The overview. The maturity level of the group to be taught should be about the junior year of senfor high school. The approximate time to be spent on the unit should be eight weoks. The teacher should be familiar with the theme in all its ramifications.

The subject-matter should be prepared in outline form, again in more detalled explanation, and again by giving additional source material. The titles of the subject-metter should be: The Origin of Folklore, The Folk Tale, The Folk Song, and The Syperstitions of the Folk. The reference outline should give the teacher thescope of the unit and point her to the sources where additional information may be obtained. Questions should be made so that pupils may think through the situations and arrive at their own definitions, generalizations, and conclusions.

The subject-matter on the origin of folklore will give the teacher much of the necessary information concerning the origin of myth and legend. Samples of Hoosier folklore w1ll reveal to the pupil many of 1ts important implications. For example, a study of "The Good Pumpkin" will show him that it is a myth representing the change of seasons, which is its hidden meaning. The samples, which the students find and bring in, show him that the idea is broad in scope, of very 
great age, and that it was primitive man's interpretation of the laws of nature. "The Loup Garou of Otter Lake" is a legend. It is definitely in the locale of vincennes, Indiana, and about local characters.

The Folk Tale. The subject-matter on the folk tale explains that the science of folklore originated with the Grimm brothers through their study of comparative mythology. This tells about the science of fairy tales and shows the difference betweon a saga and a marchen. It discusses the national characteristics of the folk tale. The students seo that some of the sagas find their way into ifterature; when they read Matthew Arnold's "Sohrab and Rustum" and Tennyson's "King Arthur," they see that the poets have borrowed from the sagas of the folk, thus preserving the traditions in poetry. The marchen, or the nursery tale, reveals fairyland and its connection with real life.

The Folk Song and Ballad. In these the subject-matter 1s explained. The dispute over the different theorles of the origin of the ballad is discussed. The distinctions between the folk song and the ballad; the themes; the places where they are in circulation; the authorities and samples of the teacher and pupils are given for the ald of the teacher in working out her plan for materials in teaching this unit. The Superstitions of the Folk. These are interpreted in the light of how they originated with primitive man and 
what man does with them today. The common superstitions are discussed and national beliefs are noted. The samples which the teacher and pupils bring in prove that many are in circulation today.

Obfectives. The writer offers the following list of objectives, some of which were suggested in An Experience Grriculum in English, by the National Council of Teachers of Engl1sh:2

1. To understand the origin of folklore.

a. To witness the action of myth and legend.

b. To exercise "poetic faith."

c. To know the important gods and their characters.

d. To become familiar with the chief heroes in the epic or cycle of legends read.

e. To realize that myths were once serious explanations of the natura I phenomena.

f. To understand the collection of legends about major heroes.

2. To collect the myths and legends in local community and state.

a. To know, understand, and use a vocabulary suitable to folklore and its orlgin.

b. To find the origin of place names in Indiana.

c. To cultivate an interest in the ir own language through the study of word origins.

d. To investigate the origin of the students' given names and the ir surnames.

e. To cultivete an intorest in local geography and history.

3. To understand the folk tale and song.

a. To learn the cultures of the people through the study of the tale and song.

4. To collect the folk tales and songs.

5. To be able to tell the tales so as to hold an audience.

6 . To learn the folk songs.

\footnotetext{
2 Hatfield, Wilbur W., An Experience Curriculum in English (Washington: National Councll of Teachers of English), pp. 251-252
} 
7. To make the lives of the students richer by recapitulating some of the experiences of their predecessors.

8. To experience vicariously the early world of men.

9. To compare present day life and thought with those of the people of other ages.

10. To gain an understanding of the mental growth of various peoples through an acquaintance with their literature.

11. To realize how the results of social and scientific progress affect our lives today.

12. To understand present day social institutions in the light of the continuous contributions of the past.

13. To participate with peoples of other times by experiencing vicariousiy their social, cultural and economic experiences.

14. To draw the community to the school and bring about a closer co-operation of teacher, student, and patrons through a study of their local lore.

\section{TEACHEF IS PROCEDURE}

Approach. There are many mothods of approach which appeal to students of the age of sixteen or seventeen. They have been taught literature, and the relating of the new field of folklore to that of literature is of fundamental 1mportance. Another effective method of approach is to connect the study about to be undertaken with the child himself -his ancestry, his comminity, his state. The teacher may relate to the pupils the origins of cortain nickmames comon in community or state, or the Christian names of the pupils themselves.

Presentation of Subject Matter. The teacher may read to her class "The Origin of Folklore" as found in Chapter IV under Materials for the Teacher. She may relate some of her own interesting experiences in the field and arouse interest 
by reading to them some of the material collected. Pupils mast be made responsible for the facts in the material presented. A check-up should be made to determine each pupil's reaction to the material and to the project, in point of information and of readiness.

Suggestions for Pupil Activity. The teacher should suggest to the pupils forms of activity which will definitely and concretely add to the development of the unit in terms of desired results. Her suggestions may include the making of blbliographies, the writing of compositions, the making of oral reports, the interviewing of persons and collecting of folklore, dramatization of tales, and many other activities. Expected Outcomes. If the materials have been clearly presented, the unit logically developed, and the pupil activities enthusiastically carried on and encouraged, the following definite outcomes may be expected:

1. The acquiring of research technique by

a. The use of the dictionary, encyclopedia, card indexes, tables of contents, and illustrations.

b. Oral and written composition. 1. Ability to use good English, to spell, punctuate, and capitalize properly.

c. Constructive and co-operative thought and planning.

2. The development of social technique by

a. Class discussion which calls for clear thinking and planning.

b. Group work in which smaller groups work together in harmony.

c. Dramatization, providing audience situation; developing poise; encouraging good posture, correct speech, and clear enunciation.

d. Providing, trrough contact with the folk, with 
librarians, and others, new soclal expertences. Correlation with School Subjects. The folklore unit, as herein planned, may be correlated closely with geography, history, art, music, Ifterature, language, drama, and industrial arts, depending upon the initiative and ingenuity of the teacher.

Culminating Activities. Among the activities which are likely to follow the development of this unit are:

1. Waking of books containing classifled lore.

2. Making of maps showing place names and locating communities studied.

3. Singing and recording of folk songs and ballads.

4. Dramatization and presentation of folk tales. Suggestions for Evaluating the Unit. The teacher will need definite means for evaluating the unit. She may do this by the use of the following check-ups:

1. Questions covering subject matter and lore brought in.

2. Oral reports.

3. Written compositions.

4. Objective tests.

Bibliography. The bibliography which follows, and which has been compiled by the author, is selective. It contains references for both teacher and pupil.

1. References for Teachers:

Baring-Gould, S., Curious Myths of the Niddle Ages London: Rivingtons, 1881.

Boggs, Ralph Steel, Folklore Chapel Hill: University of North Carolina Bulletin, 1929 . 
Cielo, Astra, Signs, Omens, and Superstitions New rork: George Suliy and Company, 1918.

Cox, George W., An Introduction to the Sciences of Comparative Mllyology and FoIk10re kegan, French and Company, 1883.

Cox, John Harrington, Folk-Songs of the South Cambridge: Harva rd University Fres s, 1925.

Fiske, John, Myths and Mythmakers Hew York: Houghton MIIIIn and Company, 1900.

Gummere, F. B., Folk Song Warner's Library of the World's Best Iiterature

Henry, Mellinger Edward, Folk Songs from the Southern Highland New York: J. J. Austin PubIIsher, 1938.

Lang, Andrew, Custom and Myth New York: Harper Brothers, 1885

MeGill, A. B., Folk Festival Louisvilie Public Library, Reference Room. Unpublished.

Needham, M. M., Folk Festival New York: B.W. Huebach, 1912.

Sandburg, Carl, The American Songbag New York: Harcourt Brace and Company, 1927.

Sharp, Cecil James, One Hundred Engl1sh Folk Songs New York: C. H. Dilson and Company, 1916.

Thomas, Daniel Lindsey, Kentucky Superstitions Princeton: Princeton University Press, 1920.

Tylor, E. B., Anthropology

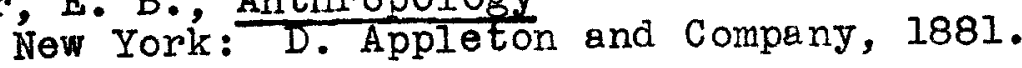

2. References for Pupils:

Anderson, Hans, Fairy Tales

M. A. Donohue and Company, Chicago, 1926.

Bowman, W. B., The Story $\frac{\text { of }}{\text { New Yurnames }}$ York: 
Bulfinch, Thomas, Bulfinch's Mythology

New York: Grossett and Dunlap, 1913.

Dunn, Platt, Jacob, Indian Stories Indiana polis:' SentineI PrInting Company, 1908

Kelley, James $P$., Workmanship in Words Boston: LittIe Brown and Company, 1916.

Lang, Andrew, Arabian Nights' Fairy Tales New York: J. H. Sears and Company.

Lomax, John A., Cowboy Songs and Other Frontier Bellads New York: Macmillan, 1929.

O'Ne11, Elizabeth, Stories That Words Tell Us London: T. C. and E. C. Jack, Lt $\bar{c}$. Sabin, Frances E.ji Classical Myths That Live Today
Chicago:

Shubert, Marie, Minute Myths and Legends

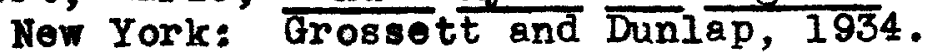

The Standard Dictionary of Facts

New York: The Frontier Press Company, 1925.

Weokley, Ernest, Romance of Names

New York: E. P. Dutton and Company, 1914.

\section{THE UNIT IN PRACTICE}

The writer spent eight weeks in teaching this unit to the junior class in the senior high school.

Approach. There are many methods of approach which appeal to students of this age, such as, "What is the essential difference betwoen literature and folklore?" The class will find that literature records man's written work, but that folklore is handed down by word of mouth. In reaching this conclusion through the tracing of some local lore, the 
students learn something of 1ts origin. The teacher began by saying, "Everyone is selfish enough to be interested in himself, his ancestors, and his community; yet sometimes strangers have to point out facts about ourselves, our ancestors, and our community which vitally concern us, but which we ourselves have overlooked. Do you not think it would make an interesting study to find out from some of these tales why we are in Jeffersonville? What brought our people here anyway? Where did they come from? You will note that there are no native Indians here. Bring to class tomorrow a short sketch of why your people came to America and settled in Indiana."

The teacher then told several stories as to why Indiana people have the nickmame, Hoosier. The Mike Fink legend is a good story, which is not very common and makes quite an appeal, as he was the reputed keelboat hero.

She related the origin of the Christian names of certain pupils, anc invited the class to find the origin of other names, both given and surnames.

"Charles Poindexter has an interesting name. The name 'Charles' is of Teutonic origin and means strong, manly. The name 'Poindexter' comes from the French word 'poingdestre,' meaning 'right fist.' Charles may be able to find how his ancestor came to have that name." 
Or, "What does the word 'Indiana' mean?" Find other place names.

Procedure. The teacher familiarized rerself with the scope of the unit by use of the reference outline on subjectmatter, which is given under "The Teaching Unit."

Since the pupil of this grade level came in contact for the first time with the technique of folklore, the teacher spent much time in acquainting him with the subject and with the ways to gather this lore, identify it, and classify it so that his knowledge might form the basis for further study.

The teacher felt the importance of the student's learning something of the subject before he should attempt to collect information concerning folklore. In the suggested approach she has tried to orlent the student in the subject, and to gain his interest in folklore by relating it to his own natural interest in self.

The students were then initiated in the procedure to be employed in making their contects with members of the community from which they expected to gain additions to their funds of folk tales; for example:

"Mary Alice, how do you introduce yourself to a stranger? Do you try to think of something you have in common with this person, or do you try to get what you can from him im- 
mediately?"

"Come before the class, Mary Al1ce, and, Frank, you pretend to be the old man from whom she expects to get folklore. Dramatize this interview as well as you can. The other members of the class will act as critics. They may make suggestions to improve your dialogue."

This activity in oral and written expression and soclal technique produced pupil learning. It helped to give students the ability to meet people graciously; to remain courteous in the face of indifference or rudeness; to persuade rather than to argue; to arrange beforehand a check list of questions to be asked in an interview. They learned to think the situation through before giving an interview. They learned to speak correctly and to record accurately the legend, tale, or song acquired.

The teacher then passed to the class mimeographed information sheets with the laws and regulations for collecting folklore.

She asked certain pupils to write, in dramatic form, an interview between an old settler and a member, or perhaps two members, of the class. A committee from the class was selected to read the papors, and to choose the better ones to be read to the class. The comitteo members were requested to proof-read these interviews, noting the misspelied 
words, mistakes in grammar, punctuation, and expression. The dictionary and English texts were used when there was any doubt as to the correct form. Some differences of opinIon arise as to the accopted social practices. The teacher had at hand a copy of Emily Post, which was used as authority for reference.

The writer, in teaching this unit, placed a list of books on the bulletin board. She asked for volunteers to find out how many of these books are in the school library. She chose two girls to get this information for the class. They checked these books on the list. Another group of volunteer workers went to the Public Library and found what reference terial is there. The librarian told the students to make a list of the needed books, so that she could buy as many as possible for them at this time. Another group went to the Loulsville Library and found the avallable books there. As a class project, they wrote letters to the Indiana State Free Lending Library. The letter was written on theme paper. The class discussed the form of a business letter, and after they had written the inside address as the teacher dictated, they wrote the body of the letter themselves. The teacher collected the letters, corrected them, and chose the best. Then 1t bocame the student's responsibility to see that the letter was typed on school stationery and mailed. 
In making use of the pupils' social experiences, in school and in the community, the teacher had insured their activity in the learning process, by means of some of the aforomentioned projects and problems. These life situations have made the students consclous of being social members of a democratic society, in which each has a share in the responsibility for the success of the group in acquiring a knowledge and appreciation of their community's heritage.

The teacher read the information on The origin of Folklore to the class with the understanding that the students were to be responsible for the terial. Then she asked them to take from dictation the following questions:

1. What is folklore?

2. How old is the sclence of folklore?

3. Why is it important to gather folkiore now?

4. What interpretation do mythologists give for the origin of myths?

5. What is meant by animism?

6. What interpretation do anthropologists give for the origin of myths and legends?

7. What is the difference between a myth and a legend?

8. What are good definitions for myth and legend?

9. How many myths can you find about the sun?

10. Why are there so many myths about the sun?

From the reference outline she assigned to individual students separate myths and legends to be reported on. Tho next day the class listened to the oral reports of these myths. The teacher gave other points to help the students grasp the information. When the teacher was satisfled that the students were clear in their interpretation of myths and 
logends, as shown in their class discussion, she told them to write the answers in their note books to the questions dictated. In this activity the students learned to listen, to remember what the heard, to discuss intelligently the origin of folklore, to formulate good definitions, and then to record what they had heard, discussed, and doduced. Furthermore, the oral reports provided an audience situation, which is always an opportunity for the speakers to develop poise, good posture, good speech--that is, correct enunciation, pronunciation, diction, grammar, as well as tone of volce. Besides, this activity gave the audience an opportunity to develop good manners in such a situation, appreciation of the good offered, and many other social experiences. The teacher read some of the folklore which she had collected in Indiana. "The Loup Garou" stories found in Vincennes show that there are French and Spanish peoples in Indiana. "The Good Pumpkin" is an excellent example of a myth, while "Donna Marianna Gonzales" is a legend. The class was quick to seo the characteristics of myth and legend as illustrated by these tales. The teacher told some of her interesting experiences while collecting lore. For instence, the woman who gave her these stories told them to her as she remembered them to have been told by Fellx Bauchie, an old Frenchman, at the celebration of King Ball, held on New Year's Eve in Vincennes. She is Mrs. Wanda Reol, who is a 
direct descendent of the real "Alice of 0ld Vincennes." The students individually were assigned outside readIng on famous Grecian, Roman, and Norse myths. They were asked to make a written report comparing and contrasting these countries in rogard to their mythology. In this project the students were taught research technique--the use of card index, the periodical index, and bibliography. They learned to consult reference books, to take notes, then to think through the comparisons and contrasts and to compare their own items. After this merial had beon checked and corrected by the teacher, the class was given the opportunity to read their compositions, so that all might receive the benefit of the others' findings.

The teacher then asked the students to go into their own community and try to secure some of its myths and legends. The teacher brought to the class an index of folk tales prepared by Stith Thompson, of Indiana University. Dr. Thomps on is president of the American Folklore Soclety. The class was taught to use this index.

Much interesting material was brought in by the pupils. A myth entitled "The Large Cabbage" was brought in by David Higdon. The class immediately identified its theme as ident1cal with that of "The Good Pumpkin." They discovered that the theme is a very old one, and is incorporated in many 
tales told by many different peoples in many different tongues. Among these tales, Jean thuter found "The Large Cabbage" in her French text. She copied the French version and translated it into English. Dorothy Milholland found a tale entitled "The Large Turnip," the theme of which was analogous to that of the others mentioned above.

The class made its own deductions. The stories were myths; their origins were wide spread; the leading incidents wore constant; the theme was the common property of many peoples. These samples of the pupils' work are given in Chapter IV.

In this study the students employed, in simple form, the technique of a folklorist. They leamed to use the indexes of a scientific study of the folk tale. The were able to make comparisons of what they had found with the samples the teacher had given them; classify them, and record their contribution. Jean manter did individual creative work when she discovered the story in another language and was able to translate it to her own. This shows, too, that the unit has possibilities of integration within itself as well as correlation with other subjects in the curriculum.

From their study of origins they worked out the origin of their own names, both given and surnames. They used as references the Romance of Names, by W. B. Bowman, 
Stories That Words Tell Us, by Elizabeth 0:Nell, and The Standard Dictionary of Facts. They interviewed the French and German teachers and used their dictionaries and other books. Each student found his own name, its family history, origin, and nationality. He gained an understanding and appreciation of how folklore origins are tied up with language, history, geography, and many other contributing factors. This discovery was a revelation to him. Most of the students worked enthusiastically on this project. They wrote compositions on name origins and read them to the class, after they had been checked by the teacher. Each student answered to roll call by giving the origin and meaning of his given name and surname.

This study was motivated by the students: keon interest in their own names, their origin, and meaning. They enjoyed, in another audience situation, the results of their research, the information secured from the language teachers, and their own compositions.

Another study of origins was made from place names. The students were given the name "Terre Haute" and were asked to find out why this place in Indlana was so called. They got maps from the oil stations, and one student drew a large map on the board. Every time a place was found and its ortgin recorded, it was marked on the map. The students found 
the orlgin of seventy-nine place names in Indiana. Again they were given an insight into the beginnings of their culture.

The teacher talked to the students about the study of animism. She explained that primitive man thought of death, sleep, and trances as features of a spirit world. She asked the students to give reports from novels, plays, or poems in which spirits, falries, witches, or ghosts influence the characters of literature. The following list of questions on the folk tale was then given to the class for the purpose of checking information gained and ablities developed in conncection with this part of the study.

1. How must the collector of folklore report his findings?

2. How does the student learn to distinguish a real folk talo from a literary tale?

3. What is a saga? Give examplos.

4. What is a marchen? Give examples.

5. What is the underlying principle in telling a folk tale?

6. What kind of a place is fairyland? What connection do human beings have with it?

7. What is the difference in style between the Arabian Nights Enterta inment and the Panchatantra?

8. What are the characteristics of the celtic tales?

9. What did the Grimms contribute to folklore?

10. What fact is established when one finds many versions of the same story?

Several students made reports on the supernatural in Shakespeare. One showed the deterioration of Macbeth's character through the temptation suggested to Macbeth by the witches. Another showed the foiries in Midsummer Night's 
Dream luring the characters into tragic situations, then releasing them so that the comedy might end happily for all the main characters.

One student listened to a radio program and made her report from hearing Cecil B. DeMille's presentation of The Return of Peter Grimm. She discussed the idea of Peter's return after death, the supernatural agency of the spirit's correcting a mistake which Peter made while on earth, and the final bringing about of a solution to an unhapp triangle. There were other reports, all of which were oral. The students have correlated their literature, folklore, and ife situations in their use of the classics, superstitions, beliefs, and radio. In making these reports of radio productions, they became keenly conscious of the famous actors of their day; unconsclously they used their language, their tone of voice, and even acquired a measure of their histrionic ability.

In the study of the folk tale, the folk song, and the superstitions, the teacher followed practically the same procedure as mentioned in considering the myths and legends. She explained how the folk tale and ballad travel with the people. She found an old, old story at Bono, Indiana, on Road 56 between Mitchell and Salem. Mrs. Thomas Neidifferis family and her husband's family have lived there for more than a hundred years. Their old store was a post office on the post road from Philadelphia to Vincennes. The story was 
In ballad form and they, as children, learned it from $\mathrm{Mr}$. Neidiffer's uncle, who was Scotch. It is called "Grumbly Grunt." John H. Cox Identifies this in his collection of folk songs as "Father Grumble." But when one examines the various texts, he finds they correspond in all essentials to the old Norweglan folk tale, "The Man Who Was To Do the Housework," found in Lee's Folk Tales of All Nations. The Norwegian tale has more details and is more humorous in tone and spirit, but the gist of it is the same as the American ballad.

It is an interesting study for the boys and girls that this ballad, found in Indiana as "Grumbly Grunt," appears in the British isles or Scotland as "John Grumlie"; that it was brought there by the Norse invaders; that the essence of the tale is found in Norway as "The Man Who Was To Do the House Work, "

Th1s Norweglan folk tale was a good introduction to the ballad. While the students learned that the bellad and folk song are importations, they found too that ballads originate in their own state. The murder of Pearl Bryan was a local tragedy, and because pearl's head was missing, the mystery kept people wondering and talking, and so, many ballads were sung about this tragedy. The folk patterned this ballad from an old English one called "The Jealous Lover." Bettie Gibson wrote the composition on "The Murder of Pearl 
Bryan" from information obtained from her father, who lived at Fort Thomas, Kentucky, at the time of the tragedy. The class brought several versions of this ballad, which shows it is still in oral circulation.

The class learned to distinguish botween a folk song and a ballad when the teacher read the information booklet and gave them samples from her collection of folklore. She sang them "The Ballad of the Waterfell," "Jenny Jenkin," and "Montgomery's Hounds." The took note of the following: that the first was a song-story; it was objective, impersonal, and concrete, the words, or the story, being the most important element. In the second ballad they saw that the distinctive feature is the music, as the words are meaningless and the emotions of the singer, evident. The last is a remnant of old camp meeting days in Southern Indiana, when the preachers made the Devil a real character in the lives of the folk, and this is one of the white spirituals common in rural neighborhoods. The class brought in ballads and folk songs demonstrating their ability to recognize and locate this lore. At this point the teacher dictated the following questions on the folk song to be recorded in the students' notebooks and answered.

1. How did folk songs originate?

2. What is the communal theory? What authorities accept it?

3. What theory is accepted today? Who propounded that theory? 
4. What are the points of distinction betwoen the ballad and the folk song?

5. How many ballads did Child classify? Who is the authority today on ballads?

6. Who are the famous collectors and what were their con-

7. Are songs like "0ld Kentucky Home" and "America" folk songs?

8. What facts determine or serve as a test for a valid folk song?

9. Where are ballads and folk songs sung?

10. From where do the Hoosler folk songs come?

There is not a great deal to add to the procedure in the study of folk superstitions. In the study of origins, folk tale, and folk song, these superstitions and beliefs had recurred again and again. The teacher read to the class Eiste Singmaster's shorty story, "Bred in the Bone," to illustrate the belief in the pow -wow doctor. The story demonstrated better than the teacher could tell the hold some superstitions take on seemingly intelligent poople. The class discussion brought out the fact that practices simflar to those recorded In the story still exist in their community; it showed that even in this scientific age doctors of medicine and theology have to cope with witcheraft and superstition in varlous forms. Questions on this topic were dictated by the teacher to the class. The questions follow:

1. What is the origin of superstition?

2. What are the causes of superstition?

3. What is the origin of the superstition about the number thirteen? Friday?

4. Why is the folkiorist interested in the superstition of the folk?

5. What part do fairies and witches play in superstition? 
6. What is the difference between religious beliefs and superstitious bellefs?

7. What are the common superstitions?

8. Why are they preserved even among educated people?

9. What literary selections have fairies and witches In them?

10. What has science done to superstition?

Suggestions for Pupil Activity. Many activities, at once interesting and educative, grew out of the procedure followed. Among them were:

Individual Research Activities. 1. Students mado a bibllography of all the books, periodicals, and pamphlets used in the study of this unit. See Canby, opydike, and Gillum High school English, Book II.

2. They looked up in the dictionary the following words: folklore, myth, legend, mythology, and wrote the defintions in their note books.

3. They consulted encyclopedias and other source materials to find origins of the words given above.

4. They read the story of Sisyphos in Sabin's Classical Myths.

5. Other myths were read about the sun, and the students made comparisons with the story of Sisyphos. They listed in their note books the myths read and checked the likenesses and differences.

6. They read the story of William Tell. They noted what the dictionary says about William Tell. They looked for other versions of the story. They read from Baring- 
Gould's Curious Myths of the Middle Ages.

7. They read, in Bulfinch's Mythology, the origin of myths.

8. They read in the dictionary, encyclopedia, and books on names, which are on the shelves of the school 11brary, the origin of their own given names and surnames. This information was written in their note books. Care was taken to give source, derivation, and nationality.

9. They looked up the word "Terre Haute" in the dictionary and encyclopedia and found its origin. They looked for other place names in Indiana and found their origins and any story connected with these origins.

10. They read the historical markers in their vicinity, and looked for references to any legends or myths.

11. They wrote a composition on the "Origin of Folklore."

12. Books were read on the science of fairy tales. 13. Blographies of the Grimm brothers were prepared. Students found out what these men contributed to the science of folklore.

14. Books on the librery shelves were read on the folk song and ballad. Students took notes and discussed them in class.

15. Compositions on the folk song were written. Comparisons were made with the ballad. An outline was prepared 
giving origins, characteristics, definitions, themes. After the outline was made, the compositions were written. A bibliography followed the composition.

16. Students made a list of the current superstitions.

17. They typed all the material.

18. Industrial Arts classes helped in the construction of a dulcimer.

Social Activities. 1. Students read in their text the correct procedure for an interview.

2. They read in Emlly Post's book on etiquette how to make an introduction.

3. They read aloud in class the two stories the teacher brought from Vincennes, Indiana. They compared and contrasted these two stories to dotermine which is myth and which legend.

4. One student went to the board and wrote the characteristics of a myth and a legend as the class dictated them.

5. Students read aloud in class a literary folk tale and a real folk tale and discussed these types.

6. They gave trreo-minute talks on primitive man's ideas of the world and the people around him.

7. Each member of the class answered to roll call by giving the story of the origin of his own given name and surname. 
8. They went to the filling stations individualiy and secured maps of Indiana.

9. One group drew a map of Indiana the size of the road map on the blackboard. Each student gave to the map committee the place name which he found and had one member of the committee place the name on the map.

10. Students made a list of persons who they thought might know traditions, old tales, or songs.

11. They interviewed these people and secured as many myths, legends, folk tales, folk songs, and superstitions as they could find in their locality. They wrote carefully the source of the information, g iving the name, address, age, and nationality of each person who gave information.

12. They took pictures of the places and people contributing folklore.

13. They told their favorite fairy stories in class. 14. They dramatized, as a group activity, one fairy tale.

15. Each student contributed to a class program one entertaining piece of folklore. They sang folk songs and played upon the dulcimer.

Correlation with school subjects. The corrolation of this piece of work with other school subjects was made with racility and naturalness. The numbers in the following 
list of correlations refer to numbered sections under "Suggestions for Pupil Activity."

1. Reading Activities:

$$
\begin{aligned}
& \text { Reserach }-2,3,4,5,6,7,8,9,10,12,13,14 \\
& \text { Social - } 1,2,3,5 \\
& \text { Rature Activities: } \\
& \text { Research - } 13 \\
& \text { Social - } 5
\end{aligned}
$$

2. Literature Activities:

3. Language Activities:

$$
\begin{aligned}
& \text { Research - 3,8, 9, } 11 \\
& \text { Social - 3,7, 8, 11, 13, } 14
\end{aligned}
$$

4. History Activities:

$$
\begin{aligned}
& \text { Research }-3,8,9,10 \\
& \text { Soctal - 7, } 9
\end{aligned}
$$

5. Geography Activitios:

$$
\begin{aligned}
& \text { Research }-8,9,10 \\
& \text { Soclal - 3, 7, 8, 9, } 12
\end{aligned}
$$

Generalizations. The class, through research, discussion, and interpretation of the lore which the students collected, arrived at the following generalizations:

1. Folklore is much the same the world over. Remarkable coincidences of deta1l, both geographlc and cultural, have occurred in widely separated countries. Scholars disagree as to their sources. Some say that the common Aryen 
ancestry explains the common fund of folklore among European peoples. Others say that India is the great storehouse of folklore, and that her treasures flowed into Europe. Modern students of folklore are agreed, however, that the mind of primitive man works much the same all over the world, and under similar conditions is likely to produce similar funds of folklore. In other words, teacher and students of this project belleve in the poljgentsis of folk tales.

2. In primitive times, all was thought to be possible of explanation, as there was no distinction made between the natural and the supernatural. Primitive folk expla ined overything in terms of itself. The will was recognized as the most powerful force and man made nature (so he thought) do his bidding. Myths arose from an analogy of nature's manifestations with man's actions. Other forms of folklore are thought to be degenerations of myths. 3

3. The history of men was thought to be a record of their struggies, successes, fallures, and achievements; folklore was the unsophisticated tradition of the folk's own reactions.

4. Human nature in primitive times was much the same as today. Themes chosen for early myths, tales, and songs

3 Ralph Steel Boogs, Folklore (Chapel Hill, The University of North Carolina Press 1929), p. 7 
dealt with fundamental human omotions and situations.

5. Literature of great cultural centers such as Greece and Rome waxed and waned, but folklore persisted as steadily as the whole human race, which produced it.

6. The poople of Indiana, or any other state in the United States, are representatives of many of the cultures of the 0ld World. Their history, their language, their customs integrate and make a composite picture-a new product.

7. Modern means of transportation-and communication have broken down the "neighbor" boundaries, and these local tales and customs will be lost to the community and to the younger generation unless many collectors make it their business to save the lore before it entirely disappears.

8. Life was depicted in the tale. The folk tale is the epic; the folk song, the lyric; the proverb, the philosophy; and superstition, the belief of the folk.

9. All collectors should keep these facts in mind: that folk materials are not statie, but in a state of change; that they are not to collect printed material, but material which comes from the lips of persons in touch with local traditions; that it must be taken down word for word; that every silig incident or grotesque expression must be reported accurately; that all materials must have passed through a fair perlod of time; that they are to give carefully the source 
of each plece of folklore--the name, the address, the age, the nationality or racial stock of the person from whom the information is obtainod.

Culminating Activities. As a natural oxpression of the worked-out unit, these culminating activities ovolved.

1. Two books containing legends, myths, folk tales, folk songs, etc., were compiled from material collected by the students and given to the school and township libraries.

a. Material was proof-read.

b. Material was re-written.

c. It was then typed.

d. Material was classifiod,as to types of folklore.

o. Table of contents was propared.

f. Plan for compilation was made.

g. Material was assembled.

2. A committee from the folklore classes presented the books, written and compiled by the students on Hoosier Folklore, to the Jeffersonville Township Library at its last board meeting of the year, and to the school library at its last general assembly for the school year.

3. Making of a dulcimer.

a. Pupils read all available information on the subject, including references to it in the Bible; e. g., Daniel, 111 : 10 .

b. Brought to class a dulcimer.

c. Got help from school wood-work shop.

d. Made list of needed materials.

o. Worked on model.

f. Made crude instrument. 
4. Made plans for a folk festival.

a. Wrote to Berea College for information (and recoived material) as to how the folk festival is conducted there.

b. Read in May Readers' Digest the account of the folk festival.

c. Planned the program.

(1) Dences.

(2) Games and plays

(3) Folk songs

(4) Folk tales

(5) Folk drama

Evaluation of the Un1t. The writer has prepared a set of questions which she regards as pertinent for evaluating the unit. They are designed to check with the aims and outcomes. However, they are only suggestive, and must be adapted by the individual teacher to her local situation.

1. Have the students developed appreciation of or desirable attitude toward the contribution of the early peoples to their own culture?

The writer's students have, by their enthusiastic response in finding their own folklore, by doing some research, by reporting their findings, by classifying their lore, by writing compositions, by giving little dramas, and finally putting their material in book form as their contribution toward saving Indiane.s lore.

2. Do the students appreciate the part played by Jacob and Wilrelm Grimm as pioneers in the preservation and popularization of folklore?

The Jeffersonville students read with interest and appreciation the folk tales contributed by these men; they wrote biographies of the brothers from material which they themselves had collected; from these and other activities it was clear to the teacher that the $y$ had come to have a measure of appreciation for them as discoverers of the sclence of folklore.

3. Have the students improved in their ability to do independent reading; to use books skilfully; to organize research materials? 
The pupils showed improvement in their ability to do independent reading by their cholce of books and oral reports made on them. They were able to locate material and to evaluate it in the light of the knowledge of folklore gained in former lessons of the course. They read as many books as they could find on given topics related to the unit and organized the material, reproducing it in their own words in ore 1 and written reports and in compositions, and kept records of the ir findings in note books.

4. Have the students improved in the ability to take part in class discussion, and in co-operation with the group?

This reaction on the part of the students was most marked. Pupils hitherto listiess and lacing in interest made remarkable response when aroused by their own first success in securing a contribution.

5. Is there any evidence of the establishment of correlation between subjects in the curriculum and the folklore unit?

Interest in Indiana geography and history was aroused. They all had maps of Indiana and used them daily. As they were looking for origins, they learned more about the history of the state, as well as the place names which they investigated. In the study of place names and surnames the students experienced the satisfaction of learning tho derivation of certain names, and therefore had a hint as to the important role language plays in the civilization of their community. Most of the class knew some of the folk music, but the class will know more when they have given their folk festival. The writer feels that the students have a good foundation and know much of the folklore of the Ir own community and of other parts of the state. They were given objective tests on the work covered. 


\section{CHAPTER IV}

MATERIALS FOR THE TEACHER

Justification for the Use of Materials. The author justifles her suggestions of materials by the fact that books used in research in the fleld of folklore are rare. It is her conviction that lore, which she and her pupils have collected, and the methods used in securing it, mey offer helpful suggestions to the teacher in her own situation. They serve as a text book for the teacher. They contain material which is invaluable to her in the development of her own appreciation, as well as in the acquisition of necessary information.

The Origin of Folklore. Although folklore passes on through the ages by word of mouth, the collection of old tales, old songs, and traditions is comparatively recent. It was in the early nineteenth century that this science was born, yet the lore was there for centuries.

And now in many lands Death, the grim reaper, races with those who are trying to gather in the harvest. He beats them before the precious heritage is collected, and buries the lore with its victim. "Time marches on!"

Students may turn the clock backward and try to catch up as they study the origin of folklore and see what primitive man thought about his environment. From his tales about himself and the olements, it is clear that he had a 
wonderful imagination. And why not? He had no facts at his disposal to hamper his fancying and believing, so he worked out his bellefs in terms which were familiar to him and explained what he wished done.

Since he knew nothing about the laws of nature as modern science knows them, he thought something ought to be done about the wind, the rain, and the sun. He personIfled these elements and thought by the force of his will he could control, appease, reward, or even punish those powers. The natural and supernatural he explained to suit his own fancy as he let his imagination run riot. One of the simplest of the tales which primitive man made up is that of "Sisyphos, a king of Corinth who indulged often in trickery and decelt. Once he even tried to cheat Death himself. Having given the gods varlous causes for offense, he was compelled, when he died, to roll a huge stone uphill. As this always slip ed from him near the top and rolled down again, his labor was never ended." I Now in the outward world each day a bali is pushed up to a surmit and then descends. This ball is the sun. The image of the sun suggests the idea of a light from which nothing is hidden. In other stories, such as Demeter and Persephone, and the story of the Cattle of the Sun, in the

1 Frances E. Sabin, Classical Myths That Live Today (Chicago: Silver Burdette and Company, 1927) p. $\frac{\text { an }}{163}$ 
Odyssey, the Sun, or Hellos, is the one who sees all things. Therefore the word wisdom is an attribute of the Sun-god. Sophos means the same thing as sisyphos, which is the Greek word for wise. In spite of this god's wisdom, he is made to go up to heaven and then come dow -- this sentence makes the sun a prisoner.

This myth is just one story in a number of stories about how the sun was regarded by the ancients, but the important point is that the story of sisyphos represents one popular notion of the business of the Sun. Then it may be seen that such thoughts are parts of other traditions; that these popular stories may be of the same nature, and may spring from this source; that folklore is not the pecullar possession of any people.

The Romans imported the Greek myths into cities of the empire; they became fashionable at Rome, but they left no impression on the country people.

The Latins, or Romans, recognized the seed, the harvest times, the change of seasons, the periods of human and other life, the garnering and grinding of grain, but they were so like the Greeks that the growth of a Latin mythology became impos sible. The Romans added little to the store. They could not promote the srowth of the highest art of the sculptor, the painter, and the poet because their gods had no definite bodily shape. Another reason 
that the Romans added so little is that they were not imaginative, but were practical. 2

Primitive man believed in dreams and in the spirit world -- the existence of a spirit or soul as distinct from matter -- the belief in inanimate objects possessing personal life or soul. This principal is called animism. Uncultured races were ignorant of science and tried to get at the meaning of life through their senses. Such manifestations as sleep, a trance, or death mystifled them and filled then with superstitious fear. They were slow in distingulshing real death from sleep and trances. They talked to a corpse; even tried to feed it and zept it around until it became offensive. Then and only then were they sure that life had gone. They believed that the soul does not die, that his image appears to his relatives in dreams and visions. The zulu thinks a man's ahadow or soul becomes an ancestral thost when he dies. The savage thought his horse or dog had a soul, a phantom likeness of its body. He Imagined a person seen in a dream to be a real object. In a dream a human being might take the form of an object, perhaps become a tree.

\footnotetext{
2 George w. Cox, An Introduction to the Science of Comparative Mythology and Folklore. (New York: Regan French and (0.), p. I5I
} 
All these objects had souls too. The ojibwas pictured the souls of their dead leaders laden with gifts on their journey to spirit land. Other quaint relics of the old funeral custorns are to be met with. There are German villages where the peasants still put shoes on the feet of the corpse, they were the "hell-shoon," with which the old Northmen were provided for the dread journey to the next world. Elsewhere, a needle and thread are put in for them to mend their torn clothes; at an Irish wake the dead has a piece of money put in his hand to pay his way.

Animism, which assumed personality in every object and phenomonon and conceived no distinction in the kind of existence of a man, a dog, a tree, or a stone, is the principle out of which arose the various systems of spirits and deities in barbaric and ancient religions. 3

There are distinctions between myths and legends. Thougl the words may be used interchangeably in ordinary speech, when strict accuracy is required, it is well to keep them separate. Fiske defines a myth as "an explanation by the uncivilized mind of some natural phenomenon."4

3 E. B. Tylor, Primitive Culture (New York: D. Appleton and Co. 1882), p. 155

4 John Fiske, Myths and Mythmakers (New York: Houginton Mifflin and Co.), p. 128 
Both are to be distinguished from stories which have been made up by design. The story that queen Eleanor saved the life of her husband, Edward I, by sucking a wound made in his arm by a poisoned arrow is a legend, but the story that Hercules killed a great robber, Cacus, who had stolen his cattle, conceals a physical meaning and is a myth. While a legend is usually confined to one or two localities, and is told of not more than one or two persons, it is characteristic of a myth that it is spread in one form or another over a large part of the earth, the leading incidents remaining constant, while the names, and often the motives, vary with each locality. This, no doubt, is due to the fact that myths are so old, dating from a time when natives had not yet ceased to form one people. It must be remembered that the actions of the uncultivated mind are more or less alike in all places, and that the same phenomenon might in various places give rise to similar stories. The myth of "Jack and the Bean-Stalk" is found not only amone people of Aryan descent, but also among the zulus of South Africa, and again amons the American Indians. Whenever a story can be traced in this way from one end of the world to the other, or through a whole family of zindred nations, it is pretty safe to say that it is a true myth, and not a mere legend.

The myth of Jack and his beanstalk is found all over 
the world -- the idea of a country above the sky to which persons might gain access by climbing is the ldea of death which is constantly in the mind of primitive man.

This tale is supposed to represent in a figure the restoration to the earth of those fertilizing activities, which are necessary to human iffe. The harp is the wind which drives the ships and turns the mills to grind the wheat. The bags of treasure are the rain-drops that scatter wealth and plenty. The red hen is the sun that brines life to birth by its fostering heat. 5

The dictionary states that william Tell is a

legendary Swiss patriot sentenced by an Austrian governor to shoot an apple from his son's head. Mr. Baring-Gould explains that most people regard this story as a historic event because it begins with seemingly accurate date, but he finds this story in many lands with the leading incidents remaining constant though the characters differ in different localities.

The coincidence of finding so many versions of the same story scattered through countries as remote as Persia and Iceland, Switzerland and Denmark, is proof that it can in no way be regarded as history, but is rather one of the numerous myths common to the whole stock of nations. Mythologists consider the myth to represent the

5 "Jack and the Beanstalk"
Encyclopedia Amerlcana Vol. 15, p. 457 
manifestations of some natural phenomena, and the individuals of the story to be personifications of natural forces. The modern folklorists disagree as the idea that all these traditions interpret natural phenomena. :

Mr. Tylor, 6 an anthropologist, is interested in myths fron the viewpoint of man and civilization. He thinks myths are the interesting products of the human mind, sham history, fictitious narrative of events that never happened. Even historians have become confused about myths and real events, so that it is hard for the student to know what to believe and what to reject. Cultured nations have leamed from science that the sky is not really the solid vault the anclents thought it to be, but only thin air and vapor. Many old myths have to be taken out of history -- men no longer belleve in gods dwelling in palaces and holding courts in the skies; they know this is not possible; so they study the causes which led to the invention of such stories.

There is a strong desire to account for everything. This desire is strong among uncivilized people, and accordingly they make up such explanations as satisfy their minds.

\footnotetext{
6E. B. Tylor, Anthropology

(New York: D. Appléton \& Co. 1881), pp. 152-175
} 
But they are likely to go a stage further. The ir explanations turn into the form of stories with names of places and persons, and thus become full made myths. Educated men do not consider it honest to make fictitious history in this way. The untrained mind has no scruples, but Invent life-like stories of what they say did happen. Then fossll bones were found in the ground, people thought they were remains of huge beasts, enormous men, or giants who formerly lived on the earth. Sclence decides they were beasts, not giants, because the bones were not the bones of men. While the belief lasted, men's imagination made stories about these giants and their terrific doings, stories which are still told in all quarters of the globe as though they were traditions of real events. Thus the Sioux of the prairies of North America say their land was once inhabited by great animals, bits of whose bones they still keep for magic, and also they tell of the giant Ha-o-kah, to whom they sing and dance at their festivals, and who could stride over the largest rivers and tallest pines.

Another thing which in all parts of the world has set the imagination of myth-makers to work is the fact that people live in tribes or nations, each known by a particular name, such as Ojibwa, Afghan, Frank. The easy and favorite way of accountin for this is to suppose each tribe-name 
or nation to have had an ancestor or chief of like name, so that his descendants or followers inherited their tribename from him.

These are examples of the myths easiest for civilized minds to understand, for they are little more than inferences or guesses as to what may have actually happened, worked up with picturesque details which give them an air of reality. But to understand another kind of myth it is necessary to get one's mind into a mood which is not that of scientific reasoning in the class-room, but of telling nursery tales in the twilight, or reading poetry in the woods on a summer afternoon. In olden times and among untutored people, notions of the kind which still remain as poetic fancies were seriously believed. Then the sun seemed a personal lord climbing the sky, and descending, dim and weary, into the underworld at night; the stormy sea was a fearful god ready to swallow the rash sailor; the beasts of the forest were half-human in thought and speech. The world then seemed to be "such stuff as dreams are made on"; transformation of body and transmigration of spirit were ever going on; a man or god might turn into a beast, a river, or a tree; rocks might be people transformed into stones, and sticks be transformed snakes. Yet when the myth-maker is dead, his story has been told so many times by bards and priests that it would be disrespectful, or even 
sacrilegious, to question its truth. This has happened all over the world and the Greek myths of the great naturegods were of much the same fabric as those of moderm barbarians like the South Sea Islanders.

In English such an expression as that the sun is "swallowed up by night" is not a mere metaphor, but the idea is one which in ancient times people took more ser1ous1y. The Maoris have mede out of it the story of the death of their divine hero Mauri. "You may see," they say, "Mauri's ancestress, Great Woman-Night, flashing and, as it were, opening and shutting out the horizon where sea and sky come together; Mauri crept into her body and would have got through unharmed, but just at that moment the little fly catcher, the Tiwakawha, broke out with its merry note and awoke the Night, and she crushed liaur1." That this is really a nature-myth of the setting sun dying as he plunges Into the darkness, is proved by the mention of the bird, which has the peculiarlty of singing at sunset. of all the nature-myths of the world, few are so wide spread as those on this theme of night and day, where the devoured victims were afterward disgorged or set free. The Zulu story-tellers describe the maw of the monster as a country where there are hills and houses and cattle and people living, and when the monster is cut open, all the creatures come out from the darkness; with a neat touch of nature which shows 
that the story teller is thinking of the dawn, the cock comes out first, crying, "Kukuluku! I see the world." The English version of the old myth is the nursery tale of Little Red Riding Hood, but it is spolled by leaving out the proper ending which German nurses have kept with better memory, that when the hunter ripped up the sleeping wolf, out came the little damsel in her red satin clook, safe and sound.

Stories are always chanding and losing their meanings, and from age to age new bards and tale-tellers shape the old myths into new forms to suit new hearers. Considering how storles change, one must expect their origins to be as often as not lost beyond recovery. While it is often possible to make out what they came from, this must be done cautiously. What is really wanted in interpreting myths is something beyond simple guessing; there must be reasons why one particular guess is more probable then any other. Whenever a good story is told, it does not matter whether it is real or made up; it becomes part of the storyteller's stock, who puts to it any new name that will stand out, and often succeeds in planting it, not only in popular legend, but even in history.

The miracle-legend is a forerunner of the historical use of myth. The story of St. Gildas bringing the fair Trifine back to her castle with her head in her hand, and 
his afterwards putting it back on her shoulders, is sham history. It records the intellectual state of the age when it was held edifying to tell such wonders of holy men. Old tales which seem extravagant in this day are likely to have historical value by poiniing to the time when they were made. Among the Budahists, these tales are told as incidents of the nany births or transmigrations of the great founder of the religion. Buddha took the form of a bird. That millions of people should have these myths as part of their sacred literature is a fact of interest in the study of civilization, warning us not to cast aside a story as worthless, because it is mythical. For understanding the thoughts of old world nations, the myths tell much we can hardly learn from history. Mr. Lee in a recent publication explains that mythology plays an important part in Iolklore. Though not synonymous with the pure Marchen or folktale, the myth has been termed "the poetic-fruit of the great struggles of the early life of a nation." Folktales may represent degraded mythology or they may be mythology in the making. "The myth is, as it were, the folktale under the artistic influence of the craftsman, and the philosophic influence of the thinker."7

7F. H. Lee, Folk Tales of $\frac{\text { All }}{\text { Hations }}$
(New York: Tudor Publishing Co. 1930 ) 
Many myths and legends have been preserved to us by mythologists and anthropologists, but many more are being lost to the race for lack of a recorder. Those which follow have been collected and recorded by the author and her pupils, through personal contact with the rapidy vanishing pioneers of their Hoosier community and state. 


\section{THE LOUP GAROU TALES}

\section{The Good Pumpkin}

A long time ago every one had his own garden. It was a pride and joy to him so he gave it great care. Jacques Cabaissoo loved the pumpkin best of all the products of his garden. He fertilized and watered the ground on which it grew. No one else had a pumpkin 11ke Jacques. Therefore the pampkin paid him back for his care and grew big. Mny of the French had gardens on the bottom side of the Ouabache River and went across to work. Jacques went many more times than the others. One cold dark night in the late fall as the wind and sleet blew across the river Jacques started hom but he never got back. His wife, children, and friends looked for him. The river turned to ice so everybody sa1d poor Jacques was dead. He was frozen. He $w 111$ come no more to Vincennes.

The winter was long and cold. The river was frozen for more than three months. Christmas and New Years are sad for Madame Cabaisseo and her fam1ly--no kin, no father or husband. Kany thought the winter was bewltched. That February the sun was so warm the trees started to get leaves; the 1 ce all went awey in the river. Then some man sair a bid gold cup in the middle of the Ouabache. He thought he sam some one come from the cup--it was Jacques Cabaisseo riding on his horse. Everybody looked and watted for him as he rode from 
the gold cup up the river bank. He and his horse are covered in gold. He just laughed and threw pieces of gold in the crowd. Charlie Page caught the gold plece for he is scared and then he said, "Jacques, if you are allowed to tell, stop and tell us the whole story."

Jacques laughed and said, "Oh, it was only ninety-one days and it was my good pumpkin loup garou, so I can talk now. I was down to the farm on the other side of the river. When I came back the 1ce was on top. I thought the 1ce was thick and that it would hold horse and mo, but wo went down, down, and what do you think I sar? Tho pumpkin grew round the horse and me. I did not know how long we were in that pumplin house. The horse ate the pumplin and then I did too. Somotimes it tasted like apples, then like grapes, thon like meat, and then just like pumpkin. I ate, I slept, I worried, and then I thought I would die. Then I lived and when the ice went away you saw me come with wy horse from my big lat pumpkin. Nom I told jou it turned to gold on the outside, but the inside was good to eat, all but the seeds. They turned to gold. I had my pockets full of gold seeds." Charley Page said, "I caught the one you threw when you were close to land. Wo will pull in your good old pumpkin for you." I bet it took many horses to pull. Everybody in Vincennes was happy to let his horse pull. Everybody sald he heard the wind 8ay, "Don't pull to land." It took fifty horses to get it to 1and. When the first side hit the land it turned to a rotten 
pumpkin. But the soed in his pocket was gold. On the other bank it makes a hill of ripe pumpkin as big as the barn. You laugh? Why?

Oh, who could belleve this story? A pumpkin big enough to hold a man and his horse. Big enough to furnish them sustenence for three months and then have some remaining to make a small hill out of 1ts golden walls.

You must know it was good loup garou to save the life of the man that took good care of him when he was just a small pumpkin and gave good measure in his seed. There vere more than nine hundred and one.

To all the questions as to how the man and the horse got inside the pumpkin without the water flowing in, how they breathed encased in the golden water-proor shell, the response 18, "You ask many questions like the lawyer, I never do. Jacques grew big lat pumpkins and regetables and he was kind and took care of all things that lived and grew and they poid him back. Now all this story isn't true but I like to make jou laugh and ask questions." 
The Loup Garou of Otter Lake

Yes, yes, this 1s true, in fact I know it is. In the Spanish days of Vincennes, there lived here very, very pretty senorita whose name was Donna Marianna Gonzales. Her father was Don Samon Gonzalez and he was proud, so proud Indeed, that he did not want his little daughter to wod young Dupree. My friend, young people in that day as in this find a way to get together, so one day they went to otter Lake, to Plsh, to hunt, and to boat ride. Then her father gave strict orders that she should go to St. Genevieve, the Spanish town on the other bank of the Mississippl below Kaskaska1. Donna Marlanne knew her father's word was law and when she went to Saint Genevieve she mast marry with old ugly Don who was very rich. He was her father's very dear friend, though they say he was so old and ugly. No one was very much surprised when he did not see Donna Harlanna for a fow days, because her father told everyone that joung Dupree could see her no more until she was married.

One day some French were hunting, and some were fishing at Otter Lake, and they saw a beautiful face which floated round and round on the water, very beautiful when far away. Then when they fished it out it was Donna karlanna, the lovely daughter of Samon Gonzalez. 
For many years the French who trap and fish in Otter Lake heard the sad moan of the drowned daughter or her song which she used to sing when she was at the King ball--such songs--such a volce--ahl I cannot tell how lovely she sang, nor how beautiful she was. Her father wanted her to be queen at the ball--he was so proud and so hard. Donna Marlanna loved Dupree and not her father's friend, so she threw herself in Otter Lake rather than marry the old man whom she could not love. So wany say they heard her last song as it went out to her lover as she struggled in the water.

My friend, these sounds make your hair stand up when you are out at Otter Lake after dark and hear what sad cries come across the water and lights like two eyes which go round and round with moens.

Then, if any wore breve and tried to catch the lights, they flicker here, there, around yonder--back of him, then before him--all the time out of his reach. Then they were lost in the water and went away with awful mad groan. No, no, I heard them not, for I never went to fish where the woman was drowned.

I like not the taste of water when I think of Donna Marianna Gonzalez. 
HOOS IER FOLKLORE

\author{
How Indiane Got Its \\ Nickname - Hoosier
}

There are meny legends about how Indiana got its nickmame, Hoosier. H. I. Mencken, an authority on the American language, said one is as good as another because it really is folklore--just tales pessed down with realig no historical data which can say with authority that this or that is true.

Ester V. McNitt of the Indiana State Itbrary discovered a clipping taken from the Pittsburgh Statesman by the Logansport Canal Telegraph of Hay 17, 1834, about the origin of the term Hoosier, which she sent to the Indiana Yagazine of History. It is one of the earliest of the several explanations that have been offered in regerd to the origin of the appellation Hoosier, so universally used to designate a citizen of Indiana.

"Hoosier. . The Hoosier State. . The good citizens of our alster state (Indlana) have been called Hoosiers for some time past at home and abroad, sometimes honorably and somotimes tho reverse. - as the term has become generally known; before that section of the public lands were regularly survejed. - many families located there were called squatters - - the survejor on finding one of these would a sk who's here, and place the name on his map. - the question became so 
familiar, that, on the first view of the smoke of a cabin, the exclamation of another who's here became equally so, until it eventuated in the general term of Hoosiers."

Richard Johnston, Boonville oditor, disagrees with this tale. "It is a pretty but a made-up story to illustrate the poom, 'The Hoosier Nest,' by John Finley, first to give literary employment to the word "Hoosier," Johnston insists. He explains: "In 1830 Finley published in the Indianapolis Journal the following glimpse of a settler's cabln which a traveler hailed at night fall. Recelving an invitation to onter, the stranger saw---

-. half a dozen Hoosieroons, (children)

With mash and milk, tin cups and spoons,

White heads, bare foet and dirty faces

Seemed much inclined to keep their places;

"At h18 host's humble board the stranger made an inventory of the cebin's contents :

One side was lined with divers garments, The other spread w1th skins and varmints; 
Dried pumpkins overhead were

strung,

Where venison hams in plenty

hung;

Two rifles placed above the

door;

Three dogs lay stretched upon

the floor;

In short the domicile wes rife

With specimens of Hoosier lifel"n

"Who's hyer?" as an explanation of "Hoosier is too palpably a dramatization of the finley poem to be convincing, sayo Johnston, and offors this suggestion: "With talent and genius for fighting, brawling and blasphemous boasting that was never matched, Mike Fink, the Paul Bunyan of the keelboat ora of river trade, and the greatest keeler that over pashed a pole on the river 0-hi-o, gave Indiana poople their distinetive name of Hoosier."

Mike Fink clalmod he was half-horse, half-alligator, tipped off with snapping turtlo.

"I'm Mike Fink, king of keelboatmen. I can outrun, outhop, outjump, throw down, drag out and lick any man in the country. I'm a Salt River roarer and a ring-talled screamer, I love the wimmin and I'm chock full of fight," was his boast. 
"In the Southern state of Georgia and the Carolinas the word 'Husher' is used to describe big, gawky person from the country. The word came to them, through the oarly colonists, as 'Hoozer' out of the particular Cumberland dialoct of Old England, moaning, big, important, large."

"Mike Fink was that kind of super-man--a 'Hoozer.." He belleves his conclusions will help to weight the gamut of discussion in behalf of claimants for "Hasher," a Cumberland, England, and Southern United States word meaning, "an important man who can hash his antagonist--hush him up with fists, guns or words."

From it develops the origin and meaning of the word "Hoosier" which camo into existence teast 125 jears ago, for Editor Johnston has a theory that "Hoosher" (note the opelling) was used as early as 1813, the jear Warrick County came Into existence as the fifth and dominant county of territorlal Southern Indiana.

The meaning of the term "Hoosier" as interpreted by George S. Cottmen, Indiana historlan, is as follows: In 1840 Indiana was the most illiterate of all the Northern States, and that in succeeding years it wes worse jet; wo are forcod to admit that its standard was low. Indeod, the most probablo explanation of the nicknamo "Hoosier" is that it was a term imported from the South, signifying an uncouth, Ignorant 
person.

The interpretation which has been current around Southern Indiane and the one which came to me by rord of mouth is that the pioneers of Indiana, wary of every atrenger, called from their cablns, "Who's here," which orolved Itself into "Hoos 1er." 
81

SAMPLES OF HOOSIER FOLKLORE CONTRIBUTED

BY THE STUDENTS OF JEFFERSONVILIE HIGH SCHOOL

\section{OLD TALES}


Informant: Mrs. M. C. Higdon

Address: 3185 th Stroet

Jeffers onvilie, Indiane

\section{Age: 81 Jears}

Hationality: Germen

\section{THE GREAT CABBAGE}

During childhood days I heard tell of a man who raised the largest cabbage over. They say it was so big it roachod across a ten acre fleld and that ono loaf covered a whole regiment of soldiers--and that wasn't all. Cattle and stock from all round about camo and sheltered under the leaves of the cabbage and ate of 1 ts sweet julcy leaves. To match this tale, I can romomber hearing a neighbor talk about the large kettle which must be made to cook the cabbage in. Thousands of men worked on this kettle for months before it was built. They say a railroad ran through it so that the men could get their pay on payday. When it was quitting time the men dropped their tools in the kettle and when they came back in the morning the tools were just hitting the bottom.

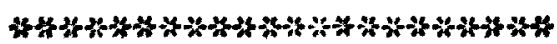

The story of the large cabbage was told to my grandmother, by two men who were trying to tell the tallest tale. One man told of the cabbage and the other man about the kettle 
which was to cook the cabbage and that is how the story goes. It was probably handed down from one generation to another, until it was finally passed on to me. This story had its origin probably in Germany five generations ago in the days of great-great-grandparents and then on to grandmother. My uncle told of hearing this tall story a long time ago. He told it in the same manner as my grandmother with the exception of the railroad, but she remembered it after he had said somothing about it.

Contributed by David Higdon English V Age 16 jears Jeffersonville High School 
THE FOLK TALe, "ThE LARGE CABBage," IN FRENCH AND THE ENGLISH TRANSLATION

Une Aincienne Histolre Marseillaise

J'al ver, dit-il, un chow plus grand qu'une maison Et mo1, dit, L'auteur, un pot aussi grand qu-une eglise: Pourquol, un pot $s 1$ grand?

Pour contenir votre chow!

\section{An Old Marsellla1se Story}

I have seen, said he, a cabbage larger than a house And I, said the other, a pot as large as a church! Why, a pot so largo?

To hold your cabbagol 
Mrs. Roberta Burgo

French and Scotch-Irish

State Highway 31

Jeffersonvilie, Indiane

The Large Turnip

A Hinnegan had a turnip, and it grow and grew, behind the barn. It grew so very large, that when he wanted to cook it he had to bulld a kettle. Mr. Finnegan worked, worked and worked upon this kettle, until one day it was complete. When Mr. Finnegan went to get the turnip; so very, very large, ho took the horses three. He wrapped a chain around 1t, then the horses pulled, pulled, and pulled unt1l at last it came froe. Mr. Finnegan and his family peelod, peeled, and peeled upon it until at last the work was done. In order to get it in the pot he sawed, sawed, and sawed until at last he had it in bits. Then into the kettlo he put it. He cooked, cooked, and cooked 1t. Then he and his chllaren; seven, ate, ate, and ate upon it from January to May and yet it wasn't gone. 


\section{Surnames}

Kany jears a go there were no surnames. People were known as Daniel, John, James, Peter, and so on. However, a villages grew into towns, the towns grow into clties, it became necessary for people to have surnames in order to distinguish them from someone else who had the same first, or Christian name. For example, if there were too many Johns in a community, which wes often the case, one would take the name of John's son or son of John in order that he could be distinguished from the rest. Hence the common surname of today, Johnson. Looking up the origin of names is quite interesting because one runs into all sorts of odd things. often wo find that pooplo were named after animals. Such is the case with the name Leach, which means dog. Others were named for their occupation, as the name Connor, which means colner, or one who makes money from metals. St1ll more often people were named for their appearance. A fow examples of these are: Blackman, Whiteman, Brown, L1ttle, Small, and many others too numerous to mention. All surnames can not be traced, because they have been changed by their ownera; sometimes they heve been enlarged, however, most generally they have been shortened by dropping a syllable or a prefix. 
Origin of Surnames and Christian Names

In the beginning people only had Christian names, most of them being taken from the Bible or from the Hebrows. For example; Rachel in the Bible named her first son Joseph, which meant addition, for she wanted more children, thus the first Joseph was named.

Some people named their chlldren after a certain pecullarity the child might possess. Others were named for precious stones, flowers, animals, or a pecullarity of clothing. The Jews often named children for sorrow, trouble, or an unhappy event which had taken place at that time. The Romans usually gave their children names of foy and happiness. Finally the time came when there were so many Johns or Marys, otc., that people would call them son of John or John's son (which became Johnson) and thus a surname or super name was adopted. From this beginning, came the 1dea of taking a surname from the occupation the person was engaged in, such as; Smith, from which we also get Goldsmith, Silversmith, Blacksmith, and etc. Tallor, baker, shoemeker, and carpenter are other occupations which are an origin for surnames.

A person might have the name of Long, Short, or Tall and still not possess any of these qualities, elthough the first ones to bear these names probably fit them perfectly. Other sources are: the long names of the Puritans, some of 
which are Praise-God and Barebones; from places in England, and still others are shown in the nationality.

By Rachel Bliss

Age 16

English IV 
Mr. Horman Elrod

509 Konwood Ave. Jeffersonville, Ind. Scotch-Ir1sh

The Legend of the Yellow Haired Giants

Back in the 12th Century Prince Madoc and his army of Welchmen were killed off by Red Indians. Their descendents wore called White Indian or Yollow Halrod Giants.

These men were supposed to be seven feet tell. When one dled or was killed he was burled with much coremony. For the burial, tomb was made; first they dug a hole, and in it placed a largo slab of stone, they thon built up the sides with large flat rocks. He was then placed in the stone box in a sitting position with his legs drawn up. He was placed facing the rising sun, as was an old Indian custom.

The following inscription is on the marker, at the corner of Harrison Avenue and Riverside Drive, in Howard Park: White Indians

A Prehistoric Indian Village Site, According to Logend, Was Peopled By White Indians, Who descended From 12th Century Welchmen Led By Prince Madoc, And Dostroyed By Red Indians. They are supposed to be burled along the river, at the 
lower end of Howard Park. If you find one of these stone boxes and get the body out whole you w11l be $\$ 10,000$ richer, so saya a man in St. Lou1s, for he will roward you. But if you do you would ruin a good legend, for 1t then would be his tory. 
Informant: Claude B. McBride

Address: 117 East Riverside Drive

Jeffersonvilio, Indiana

Age: 56 jears

Nationality: Scotch-Irish

The Logend of Dead Man's Hollow

About the year of 1850 , where the road crossing Dead Yan's Hollow is now located, was at that time a dense forest and no road had yet been bullt across the hollow. This was a very deep hollow, which was donsely over-grown with the original forest. During very severe winter, at which time a heavy snow lay on the ground, a strange man was found, frozen to death in this hollow. Ho was found by John $R$. MeBride and Isaac Hale, my great-grandfathers. There were no papers containing his name or marks of identification and his identity was never learned and it was presumed that he had been lost In the dense forest, which then extended over a great area, and froze to death in h1s wanderings. H1s body was the first corpse buried in the Hale Cemetery, which is located a short distance South of Dead Man's Hollow and from this incident the hollow was named Doad Man's Hollow.

Contributed by Margie McBride Age 16 years Jeffersonville High School English V 
Informant: Mrs. Herman W. Elrod

Address: 509 Kenwood Ave. Howard Park

Age: 49

Nationality: Dutch

Why Children Were Called KIds

Many years ago in Boan Blossom, a suburb of Elliotsv1110, Indiana, mJ grandmother, Rachel Fampler, told me this story.

"When your father was a baby we fed him on goat's milk. The older children fokingly said, willie is a kid, because his mother is a goat. "n

Similar atories have been told from all over, saying that it started in their family.

By Tom Elrod

English VI 
The first division of the subject matter explained the myths and legends. The next deals with the folk tale and the fairy tale, the stories which have fascinated the children of the world. Some of these tales are preserved in literature, but the folklorist's interest lies in those found in oral circulation today.

TIIE FOLK TALE. "Tell us a story" is a command which was never confined to the nursery; in fact, the art is one of the most primitive practices of the human race. Before primitive peoples could write or read they told tales one to another, and from these there have come vast numbers of traditions which express the instinctive feelings of Immature tribes and races in a kind of storyphilosophy. Manners and customs change; yet some of these old stories have survived the passing of centuries, and it is worth while to remember those other days, when Iffe, though more primitive, afforded more time for simple dreams of wonderful things.

People vegan to value the popular traditions just as they began to decline and disappear. There were a number of factors which brought this about -- the spread of book-learning particularly, as well as the breaking down of geographical barriers, led people into other modes of expression. 
Folk tales have been described as "the little novels of childlike intellects:"8 They belong to and come from a class whose daily Iife lies close to the earth -- tollers In the field and in the forest, who tell with simple directness, in stories or charms, their impressions of the natural or supernatural forces with which their lives are surrounded. The tales were told primarliy to amuse, but they contain nevertheless the key to ideas and powers of thought, to customs and beliefs, of the primitive mind. Life was told in a tale, not explained by a philosophy. It should be remembered that a good folk tale is essentially dramatic, and the very act of comritting these oral traditions to writing lessens their intensity and porer.

National differences in the manner of story-telling are for the most part superficial. The faithful delivery of the tradition is the principle underlying all varlations of manner, and it is not confined to any race or people. Changes do take place as the story passes from one to another. The student must know something of the habits, the national and social surroundings, and the modes of thought of the people whose stories he examines.

The folklore which is collected must come directly

8Lee, F. H. Folk Tales of All Nations (New York: Tudor Publishing Company, 1930), p. 3 
from the lips of the story-teller, and be set dow with accuracy and good faith. Every turn of phrase, awkward or coarse though it may seem, must be reported. Every grotesquery, each strange word, every incomprehensible or silly incident, must be given without flinching. The student soon learns to distinguish the collections whose sincerity is certain from those furbished up by literary art.

Fairy tales fall into two classes; namely, sagas and harchen (nursery tales), which are not confined to fairy tales, but include all stories which are looked upon as narratives of actual occurrences. The sagas come first In the history of culture and they are the most persistent. They find their way into literature and are thus rendered imperishable. "RIp Van Hinkle" and "The Story of King Arthur" are saǵas. Marchen or nursery tales are told simply for amusement. "Cinderella" and "Puss in Boots" belong to this class. They treat of incidents believed in other countries, or in other stages of clvilization. No one has to believe the story, but the nursery tale must end happliy for hero and heroine. Fairy tales of both classes are made up of happenings which are the common property of many peoples and many are known all over the vorld. 9

\footnotetext{
${ }^{9}$ Hartland, E. S. The Science of Fairy Tales (Scribner \& Welford, New Tork, 1891), p. 108
} 
Savage philosophy regards animate and inanimate objects with a personality far more clever and more powerful than man is endowed with; consequently these spirits are to be dreaded, appeased, and sometimes punished. Fairyland is a very human place where fairles entice mortals, and those who enter and partake of fairy food become spellbound and have not the power to return to earth. They marry, have children, are sometimes happy, sometimes sad. Fairies are grateful to men for benefits conferred, and resentful for injuries. They make things seem other than they are.

There is scarcely a boy or girl in school today who cannot remember the thrill of The Arabian Nights Entertainment as Aladdin rubbed his wonderful lamp or ring which brought to him two frightful genil to do his bidding; or spellbound, heard the cry, "New lamps for old; who will buy new lamps for old?" Written in much the same style is a collection of tales from India called the Panchatantra or The Five Books. The stories, composed for the amusement of a Brahman princess, date as far back as 200 B. C. They are not so elaborate as The Arabian Nights. The theme concerns itself usually with the dangers of Ilstening to vicious gossip about one's friends and the advantages of working together to help one another. The English version of The Arabian Nights appeared in about 1840, and from Dr. 
E. W. Lane's translation children get their fairy tales free from the coarseness of the original and very similar in tone to the Panchatantra. India must be acknowledged as the home of some of the oldest folk tales of the world. The delightful, romantic elements are missine in the Indian tales and are replaced by fantastic beliefs full of superstition. They are very much like "the hot house plant -. forgeous in color, rich in perfume, precocious and abundant in fruit." 10

The English, Scottish, and Irish lore have kindled the imagination of many poets. Their lore is full of superstition too, and pictures all types of fairies. The lively elves, the dainty queen $\mathrm{Hab}$ and her courtiers, the mischievous bromie, the domestic banshee, the magical dwarf, the fantastic little leprechaun, the wilful Puck, the little hill-people, and the good little people, as well as the Grotesque and terrible ogre, the giant, and the dragon, all play important roles.

The English tales delight the simple people in their quaint, pleasing way as they meet their fairies in a charming setting while they are led from one adventure to another. Their Scotch neiuhbor tales are more serious and romantic and lack the humorous twist found in both the English and

$10_{F} \cdot$ H. Iee, Folk
(New York: Tudes 
Irish tales. With a touch of the old world about them, the Irish tales invite young and old into their land of make believe. They go with the sensative impressionable folk who cherish the supernatural and rejoice in the presence of spirits -. the "good people" whose rights they never fail to respect. They love life; they revel in the dance and the feast; and while there is a great deal of humor, the pathos is there too, in their tragic stmaggles for existence.

The name Grimm brings happy recollections as men, women and children remember their fairy tales. Jacob and William collected household stories from old dames and nurses in their native Germany as well as from other places in the world. In this collection there is a striking similarity. Certain plots, incldents, and basic elements appear repeatedly -- that is, the youngest son is wiser than the other two; the younest daughter is generally 1ll-treated; the false bride is substituted for the true one; a supernatural husband or wife chooses a human wife or husband; inanimate things are transformed and made capable of speech and action. From these tales the Grimms worked out a sort of comparative mythology, and it was through their study and interpretation that the science of folklore was bom. English readers are familiar with French folklore and many of the stories are regarded as their very own. 
The French tales do not ring quite so true to life as do the Inglish. The simple life is not there, but rather a romantic mockery, wich presents the ball room, the court, and leaves the reader with a sense of superficiality regarding the plctures.

The Spanish folk tales are in substance very much like other European stories. They are delightful in their native setting. The Spanish peasant is intelligent, imaginative, and superstitious; he loves to act out these tales, which are weird and tragic, for his folk who enter into the spirit with him.

The study of these stories which show fundamental likenesses must help to promote understanding and to widen sympathy. Mr. Baring-Gould has classified folk tales into seventy types, each of which has many variants. For the simple story of "Cinderella" there are at least three hundred versions.

Hoosier Polklore. The samples which follow show the student the way the folk tale travels and the way it often changes form. The old Norwegian folktale "The Wan who was to Do the Housework" evolved itself into the ballad. 
Informant: Mrs. Thomes Noldiffer

Address: R. R. No. 1, Mitcholl, Indiana

Age: 72

Nationality: Scotch-Irish

\section{Grumbly Grunt}

old Grumbly Grunt came stomping in, He'd just beon on a spee, spreo; He swore he could do more work in a day, Than his wife could do in throe three; He swore he could do more work $\ln a$ day, Then h1s wife could do in three, three.

$$
2 .
$$

Mrs. Grunt came limping in, I'm coing to have you now, now; You can do the work in the house, While I go follow the plow, plow; You can do the work in the house, While I go follow the plow, plow?

\section{3.}

But don't forget to wind the jerm, That I spun josterday, day;

And don't forget the speckled hen, or she 111 run away, way;

And don't forget the speckied hen, or she will run away, way.

Don't forget to feed the $\mathrm{p} 1 \mathrm{~g}$, That stands within the sty, sty; 
And don't forget to milk the cow, Or she will go dry, dry;

Don't forget to milk the cow, or she wlil go dry, dry.

\section{5.}

Don't forget to churn the cream, That stands upon the frame, framo; And don't forget the fat in the pot, or it will all go into flamo, flame;

Don't forget the rat in the pot, Or it will all go into flame, flamo.

6.

He wont to wind the spool of yarn, That she had spun yesterdey, day; And he forgot the speckled hen, And she did run amay, way; He forgot the speckled hen, And she did run away, way.

$$
7 .
$$

He went to churn the jar of cream, That stood upon the frame, frame; He forgot the fat in the pot, And it all went into flamo, flame; He forgot the fat in the pot, And it all went into flame, flame.

8.

He went to feed the little pig, The t stood within the sty, sty; Ho bumped his head against the beam, And how the hair did fly, fiy; Ho bumped his head against the beam, And how the hair did fly, fiy; 
9.

He went to milk the muley cow, And how she kicked and moaned, moened; She kicked old grumbly on the shin, And the blood ran down to his toe, too; She kicked old grumbly on the shin, And the blood ran down to his toe, too. 
American Ballad

There was an old man who lived in the roods, As you shall plainly seo,

Who thought he could do more work in a day Then his wife could do in threo.

"W1th all my heart," the good dame said, "And if you will ailow, You shall stay at home today. And I'll go follow the plow."

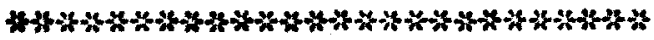

The old woman took the stick in her hand And went to follow the plow;

And the old man took the peil on his head And went to milk the cow.

But Ting she winked, and Tiny she blinked, And Tiny she tossed her nose; And Tiny she gave him a kick on the shins Till the blood ran down to his toes.

*4t

And when the old roman came home at night, He sald he could plainly seo

That his wife could do more work in a day

Than he could do in three.

Cox, John Harrington, Folk-Songs of the South
(Cambridge: Harvard University 
THE HUSBAND WHO WAS TO MIND THE HOUSE

Once on a time there was a man, so surly and cross he never thought his wife did anything right in the house. So one ovening, in hay-making time, he came home, scolding and swearing, and showing his tooth and making a dust.

"Dear love, don't be so angry; there's a good man," said his goody; "to-morrow let's change our work. I'll go out with the mowers and mor, and you shall mind the house at nome."

Yes! the husband thought, that would do very well. Ho was quite willing, he said.

So, oarly next morning, his goody took a scytho over her neck, and went out into the hay-field with the nowers, and began to mow; but the man was to mind the house, and do the work at home.

First of all, he manted to churn the butter, but when he had churned a while, he got thirsty, and went down to the cellar to tap a barrel of alo. So, just when he had knocked in the bung, and was putting the tap into the cask, he heard overhead the pig come into the kltchen. Then off he ran up the cellar steps, with the tap in his hand, as fast as ho could, to look after the pig, lest it should upset the churn, but when he got up, and saw the p1g had already knocked the churn over, and stood there, routing and grunting among the 
cream which was muning all over the floor, he got so wild with rage that he quite forgot the ale-barrel, and ran at the pig as hard as he could. He caught 1t, too, just as it ran out of doors, and gave it such a kick, that piggy lay for dead on the spot. Then all at once he remembered he had the tap in his hand; but when he got down to the cellar, every drop of ale had run out of the cask.

Then he went into the dairy and found enough cream left to 1111 the churn agein, and $s 0$ he began to churn, for butter they must have for dinner. When he had churned a b1t, he remembered that their milking cow was still shut up in the byre, and hadn't had a bit to eat or a drop to drink all morning, though the sun was high. Then all at once he thought itwas too far to take her down to the meadow, so ho'd just get her up on the house-top--for the house, you must know, was thatched with sods, and a fine crop of grass was growing there. Now their house lay close up against a stoep down, and he thought if he lay a plank across the thatch he'd easily get the cow up. But still he couldn't leave the churn, for there was his little babe crawling about on the floor, and "If I leave 1t," he thought, "the child is safe to upset 1t." So he took the churn on his back, and went out with 1t; but then he thought ho'd better first water the cow before he turned her out on the thatch; so he took up a bucket to draw water out 
of the well; but as he stooped down at the well's brink all the cream ran out of the churn over his shoulders, and so down into the well.

Now it was near dinner-time, and he hadn't even got the butter yet, so he thought he'd best boll the porridge, and filled the pot with water, and hung it over the fire. When he had done that, he thought the cow might fall of the thatch and break her legs or her neck. So he got up on the house to tie her up. One end of the rope he made fast to the cow's nock and the other he slipped down the chimney and tied round his own thigh; and he had to make haste, for the water now began to boll in the pot, and he had still to grind the oatmeal.

So he began to grind away; but while he was hard at 1t, down fell the cow of the house-top after all, and as she fell, she dragged the man up the chimey by the rope. There he stuck fast; and as for the cow, she hung half-way down the wall, swinging betwoen heaven and earth, for she could nelther get down nor up.

And now the goody had walted seven lengths and seven breadthe for her husband to come and call them home to dinner; but never a call they had. At last she thought sheid waited long enough, and went home. But when she got there and saw the cow hanging in such an ugly place, she ran up and cut the rope in two with her scythe. But as she did th1s, down came 
her husbend out of the chimney; and so when his old dame came inside the kitchen, there she found him standing on his head in the porridge pot. 
Folk Songs and Ballads. Folk songs and ballads follow the folk tale in this unit of work. The tale in Norway became the ballad in the British Isles, and in that form came to America. In Indiana it has another name, but the theme is the same as that of the Norwegian tale, and the Scotch and American ballads.

Many of the old songs begin with "Come and I will Sing you" which serves as an introduction to many themes. The one which the writer found in Jeffersonville is an old English folk song with many different versions. "The Ten Commandments", "The Twelve Apostles" are the names of the Christian versions while the Jews have still another "The Lucky Thirteen". Many of the songs introduced in this way were for entertainment.

Folk Song. "Come and I will sing you" was not always sung for amusement. Thousands of years ago, before airplanes and battleships, camon and poison gas had been dreamed of, men fought their wars with such weapons as they knew -stones, clubs, and their own hands. Naturally, when a battle started, every fighter became excited. He was fighting for his Iife. He shouted to his friends to encourage them and shouted to his enemies to frighten them.

Men who were fighting developed the custom of shouting about certain things which they liked. They may have shouted the name of their tribe or their god. Perhaps they 
yelled something to sharpen their ow anger or to ridicule thelr enemies. There was probably a great deal of bellowing back and forth.

It was like certain games that people play. Long ago the children playing these games shouted things they felt like saying.

In the same way the first war cries came to be used, and war sones must have zrown in a similar way. They grew the faster because before a battle, each army came shoutIng, and the two often stood for some time singing and taunting each other. Of course, two crowds will do the same nowadays. Yells are tossed back and forth between Jerfersonville and New Albany High Schools in much the same manner at basketball games. The rooters never do the actual work, as the fighters did in the armies, but there is a similarity between their yells, and the old war cries. Here is an Indian war son that shows how this was probably done.

$$
\begin{aligned}
& \text { Death I make, singing } \\
& \text { Hey-yeh! hey-yeh! Hey-yeh! hey-yeh! } \\
& \text { Bones, I hack, singing } \\
& \text { Hey-yeh! hey-yeh! Hey-yeh! hey-yeh! } \\
& \text { Death I make, sinjing } \\
& \text { Hey-yehd hey-yeh! hey-yeh! hey-yehd }
\end{aligned}
$$

Today seed-planting and the growing of crops are a matter of science and comion sense, but three thousand years ago this was not so. The people reasoned that if they talked to the gods and asked them for their help, 
saying words to please the good gods and words to protect the seed from those who practiced witchcraft, it would grow well. They sang little songs or chants when they planted their seeds, like this one which the old Saxons in England used:

$\begin{array}{ll}\text { Erce, Erce, Erce, } & \text { mother of Earthd } \\ \text { May the Ali-Wielder, } & \text { Ever-Lord grant thee } \\ \text { Acres waxing, } & \text { upward growing, } \\ \text { Pregnant with corn, } & \text { plenteous in strength } \\ \text { Hosts of grain shafts } & \text { and of glittering glants! } \\ \text { Of broad barley } & \text { the blossoms } \\ \text { And of white wheat } & \text { ears waxing } \\ \text { Of the whole earth } & \text { the harvest. } \\ \text { Let be guarded the grain agalnst all ills } \\ \text { That are sown over the land by sorcery-men; } \\ \text { Nor let cunning woman change it nor a crafty man. } 12\end{array}$

There were other chants like this for other work men did. In fact, son s were made sometimes to help people remember. They didn't know how to write and their songs were the means of remembering. Even today we have rhymes, which have come down through hundreds of years, telling us how to remember the number of days in a month, or to teach little children to count. When all men were children their rules for workIng and behaving and even their laws were put into poetry for safe keeping.

Ballads are poems of a very definite kind, different from others in English. They always tell a story. They

I2 Stofford A. Brooke, The History of English Literature (Wacmillan 1907) 
are by unknown authors. They were made to be sung to tunes. They were passed on by word of mouth for a number of generations, changing sometimes only a little, sometimes much, as different people sang them. They were never literary. No court poets composed them, no harpers or minstrels. They were made and sung among the common folk away from courts and cities and books.

There has been quarrelling among scholars as to just how the ballads were made, and how long ago. Some believe the habit of ballad-making was older in English than poems like Beowalf. There are no ballad manuscripts dating back to that period -- in fact, except for one frasment which may or may not be a ballad, none is older than the thirteenth century, if as old. Yet quite probably ballad-making far antedated the thirteenth century. For these poems of the people seem to have been made by groups of men and women singing together, and the custom may have gone back farther than any written English. Perhaps in some instances the ballade were sune for country dancine. Hany of them are made in four-Iine stanzas. The first and third lines are a couplet, and the second and fourth are chorus lines or refrains which all the crowd could sing:

"She gi'en to him a gay gold ring; With a hey lillelu and a howlolaw, W1' seven bright dianonds set therein, And the bird and the broom blows bonnie." 
As a group of people talked and danced, they may have put into such form, the stories of love and war which they knew. It was much like the making of early chants and songs. Some one who had a quick tongue would sing out a line:

"As long's these diamonds keep their hue," and the crowd would sing a refrain:

"With a hey lillelu and a howlolaw."

Then the first singer would match the first line:

"Ye'll know I am a lover true,"

leaving the others to finish off the stanza with the chorus:

"And the bird and the broom blows bonnie." 13

Thus, gradually, the whole story would be told. Undoubtedly some of these simple singers were poets. However, they didn't think of themselves as composing poetry. They knew they were good at helping to make ballads. About the castle rires, or on the green, in sprine, they were spurred on to make sons with the others -- sones that were good to sing, and that kept old tales and memories al ive. The ballads came out of the daily lives, the singing spirit, and the deep feelines of people. That is. why they are so much more genuine than most of the sones of the minstrels, who had little, if enyth inc, to do with makin ballads and who went the rounds of towns and castles performing for 
their living, not chiefly to express their enotions.

Scholars like Child, Gurmere, and Pound have given definitions of the ballad, however the one which is accepted by critics as the most satisfactory is Gerould's 13 which is as follows: "A folk-sone that tells a story with. stress on the crucial situation, tells it by letting the action unfold itself, in event and speech, and tells it objectively, with little comment, or intrusion of personal bias."

Mr. Bogfs explains the ballad as the epic of the polk. It tells a story of a people in verse. The ballad is to be sung and the music is an integral part $0 \hat{I}$ it; hence it is often called a IJric-epic, or sone-story. But it is objective and impersonal in tone and the story is the chief feature. It was liss Pound who made the attack on the comrunal origin, which has been a popular theory since the Romanticists in the nineteenth century. More recentiy it has been sald that ballads were coined by individual gifted poets, whose names have been effaced with much later handling by the folk.

The ballad stands very close to the folk tale in many respects. The same theme may be handled by both. The style is rather similar in both types. They follow many of the same tendencies in evolution. The treatment

\footnotetext{
13 Gordon Fiall Gerould, The Ballad of Tradition (Oxford: The Clarendon Press, 1932$)$ p. I6
} 
of the hero is very similar. The ballad tends to be concrete, and is thus apt to become bound up with the particular folk among which it finds 1tself. Probably ballads found today do not date back as far as folk tales found today.

The folk song expressing the emotion of the folk is called the lyric. It is entirely subjective and personal, as opposed to the objective, impersonal ballad. It may contain some narration, but its purpose is to permit its singer to give vent to his feeling. The music is a most essential part of the folk lyric. If the words are more Important in the ballad, certainly the music is more important in the folk lyric. Its words may be mere repetitions or even meaningless, but the music sustains the purpose of the song. A great comforter is the folk lyric. It serves the folk at work and play, in love and war. There has not been so much dispute over the origin of the folk lyric as there has been over the origin of the ballad. Since the folk lyric expresses fundamental human emotions found in the folk everywhere, it is indeed a universal type.

Songs, although universally known and sung by the poople as a whole, such as "America," "Hail Columbia," etc., are not folk songs. Those handed down by the printed page are static; traditional pieces handed on orally from mouth 
to mouth are in a state of flux. This is the most valid distinction which can be made for folk songs as differentiated from book or semi-literary verse, or from popular songs in ceneral. Folk songs must have retained their vitality through a fair period of time, and all sense of authorship has been lost by the siners. These are the only valid tests of genuine folk songs.

Ballad stories have the themes such as those listed below. There have been about one hundred and fifty ballads which deal with sex, if crimes of love and of sex violence are included; one third of the ballads deal with love in one form or mother; seventy-four, or about one fourth, are concerned with family relations or a more or less violent sort, about one half of which are based on manslaughter; sixty narrative fights and battles on land and sea; nine or ten deal with sailors or with the sea; forty-three exploits of Robin Hood are related; a considerable group have tricks and riddles; twenty-five are made up of superstitions; and eight relate New Testament miracles. The early collectors did very little with tunes. This was true of Sir Walter Scott, as also of Francis Jares Child and Sevend Grundtvis. Up to the last decade Great Britain led the way in emphasizing folk music, but now America has gone forward and is excelling in the matter of collecting ballad melodies which are beautiful and varied. 
The ballads furnish much interesting and valuable information of what has been thought and felt and done as a matter of custom, but they present no coherent record of either historical or of popular belief and custom at any one particular period. The record as a whole is precious, not because it is vell ordered and coherent, which it is not, but because it is genuine.

The interest of the ballad as a form lies even more In the constant remaking which the individual specimen undergoes.

Ballad singine was once a dignifled means of entertaining a company. There was singing at social gatherings and at games and dances of young folk, as well as on occasions of more impromptu character. Singlng of this type is now much restricted, but it lingers in out-of-the-way places, as in the chimney nook of the farm house, or by the stove in the cross-roads store. But picturesque olc songs may sometimes be heard from children who learned them from neichborine families or picked them up in the streot. In Hexico and $N_{e w}$ Mexico the folk sone and the ballad are very much alive. The Spanish and liexican peasants are very dramatic and emotional and they keep their traditions alive by acting their ballads, sons, and tales. Ballads are most al ive in the mountainous regions of the southeast and on western ranches. The more isolated the region, the better 
the chance for the survival of old songs. They may be sung to the flddle or acordion, the mouth harp, or occasionally to a cabinet organ. In the Cumberland Mountains they are still sung to the banfo or to the "dulcimore," a three stringed instrument descending from Elizabethan days. The characters and manners of the American ballads betray the varyin: origins and the divergent social groups among winlch they have Iingered. Evil stands out stark, and goodness is equally unqualified. The "true love" is simple and devoted, the parents stern or harsh; lovers are eternally attached, or faithless and murderous. Favorite characters in the imported peices are knights and ladies, apprentices from - London, lovers back from war, highwaymen, criminals and thieves. Miss Pound 14 states that on the whole the western songs are those which reflect most faithfully local conditions and characters.

John and Alen Lomax have made a study of the negro folk song in the South. These men, father and son, have charge of the archives of all folk song material at the Itbrary of Congress. They gather their material from the negro in chain gangs, prisons, cotton fields, sugar camps and cabin homes -- in fact, every place where they find him at work or play. Most of these songs do not reflect

\footnotetext{
14 Louis $\theta$ Pound, American Eallads and Songs

(New York: Charles Scribners Sons, 1922), pp. 12-99
} 
the negro as he is usually pictured -- the cheerful, carefree philosopher, but rather he is show shouting, chanting, expressin dramatically, tragically his experiences, and his sone is not a happy one.

The type of traditional songs first to claim the interest and attention of American lovers of balladry is imported; namely, English and Scottish popular baliads surviving in the United States. Something of old World legend and romance is echoed in these imnagrant songs from the British Isles which have found a home in a new land. Next in interest comes the group of American songs which are the strongest contrast; namely, frontier, pioneer, or cowboy pieces; songs of emigrants westward, of frontier conditions, and frontier characters, or of outlaws conformIng to old Forld patterns. Such are sonss of the constant or inconstant lover, of the reunion of parted lovers, of the murderous lover, or of lovers thwarted. The forsaken girl is the theme of many ballads and songs, and many pieces hinge upon the attitude of harsh parents. Besides songs from older and from later British sources, there are many which show derivations from or reference to Ireland. There are some American contributions which retain supernatural elements, or make allusion to the supernatural; but on the whole, ballads of the supernatural play a shrunken role in the New World. 
A rough classification of the remaining types of American song would include a few songs of shipwreck or of the lost at sea; some Indian or pseudo-Indian songs like "The Pretty Mohea" or "The Aged Indien"; many humorouf songs or song-stories of ten finding their chief hold upon the memory in sone single ine, such as "I Wish I Was Single Again" or "I'll Not Niarry At AII"; songs of highwaymen like British Dick Turpin, the Australian Jack Donahou, the American Jesse James, or of the pirate Captain Kidd. There are also many death-bed confessions and local songs of murders, assassinations, and disasters. There are moralities and religious songs; pathetic songs of orphans and infants; sonss of occupationel pursuits, such as farm and ranch life and rallway songs; and, lastly, traditional gane and dance and nursey songs of American children.

It is quite possible that a few old vorld ballads have been recovered in this country in an earlier form than that which survives in England. This may be true for "Barbara Allen's Cruelty" and "The Maid Freed From the Gallows." However, "The Romish Lady," dating from the era of Protestant martyrs, remains very close in its American derivatives to the broadside text of the time of Charles II, which is the earliest text of it preserved in England. Since colonial times, folk songs 
we been brought over by nearly every influx of newcomers. Immigrants from Ireland especially have brought over many songs. One "classic" from this source, much adapted and disguised, is "The Dying Cowboy."

Nothine of consequence comes to us from Colonial, Revolutionary, or Clvil War times. Some of the comic negro sones, such as, "Jim Crow," "Zip Coon," "Settin' on a Ra1l," which are still alive and in traditional circulation, date from a period earlier than the Civil War; but all types of negro songs gained inpetus during the war period, and they owe to the ieeling and the interests which were bound up with them much of their diffusion and persistence. The Cuban War, later in the century, bequeathed "There'll $\mathrm{Be}$ a Hot Time in the Old Tow Tonight" to folk sons, and the recent European war will probably leave its quota of favorites, though it is yet too early to predict which of them will find longest life.

For bal lads, a few generalizations may safely be made. A percentage reflect real events; but in general, there is little connection with history, or the connection is of slight importance.

American folk sone as a hole has been imported from the old World. This is becoming less true, but it still holds. Folk songs are still brought across the Atlantic by newcomers; and a large percentage of the most striking and 
persistent pieces current in America are derived from old World originals, English, Scottish, or Irish.

It is through singing that folk songs are handed

down. It is the music which keeps them alive.

As to the style of the ballads, some American songs are rough, frank, spirited, others picturesque, pathetic or melodramatic. The diction tends to be rugged, the meter crude, the tone unsophisticated. Though sometimes highly colored by emotion, the language of the American oral song is plain. 


\section{HOOSIER FOLKLORE}

Folk songs and ballads contributed by Miss Leah Neidiffer, Bono, Indiana. "The Bold Soldier" is an old English ballad with many different titles and versions. "The Wild Moor" is an old ballad too, which is found in almost every collection. "The Iying Rider" patterned after "Mother Goose Rhymes" is English also. Nottingham is an English city and county. 


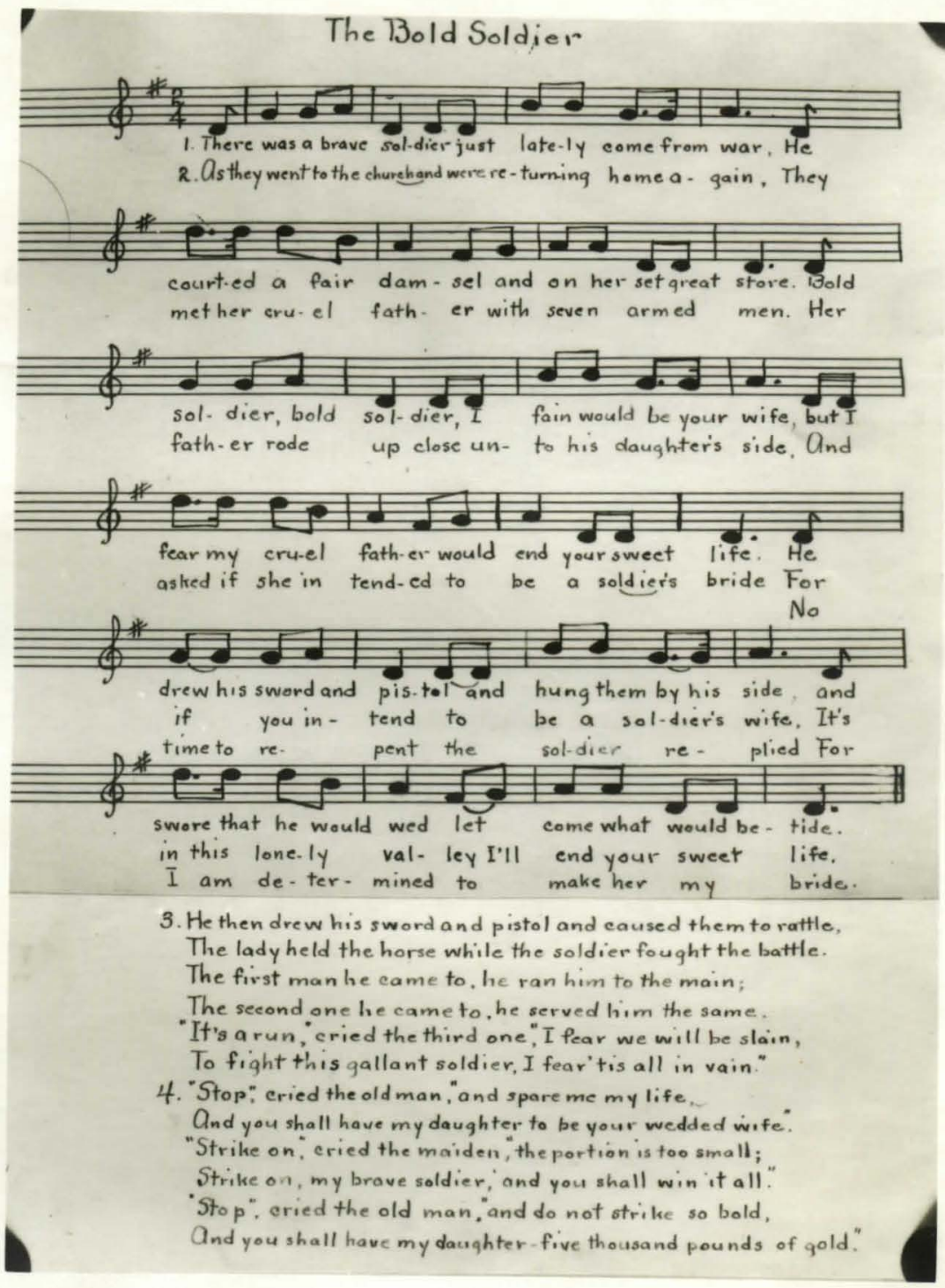


The Wild Moor

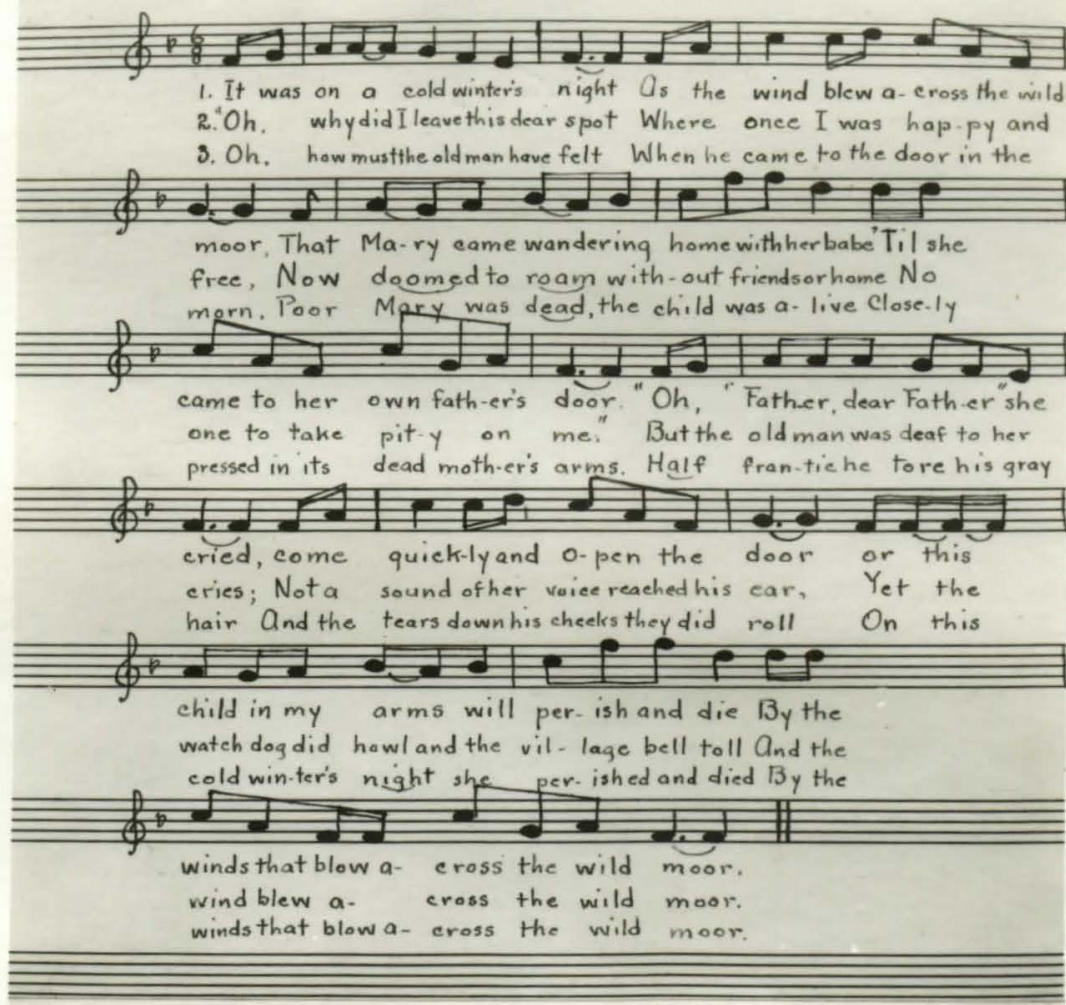

4. The old man in grief pined away.

The ehild to its mother went soon.

And no one, they say, has lived there to this day,

And the cottage to ruin has gone.

The villagers point out the spot

Where the willows droop over the door,

Saying 'Twas there Mary died, a gay village bride,

By the winds that blow aeross the wild moor. 
The Lying Rider

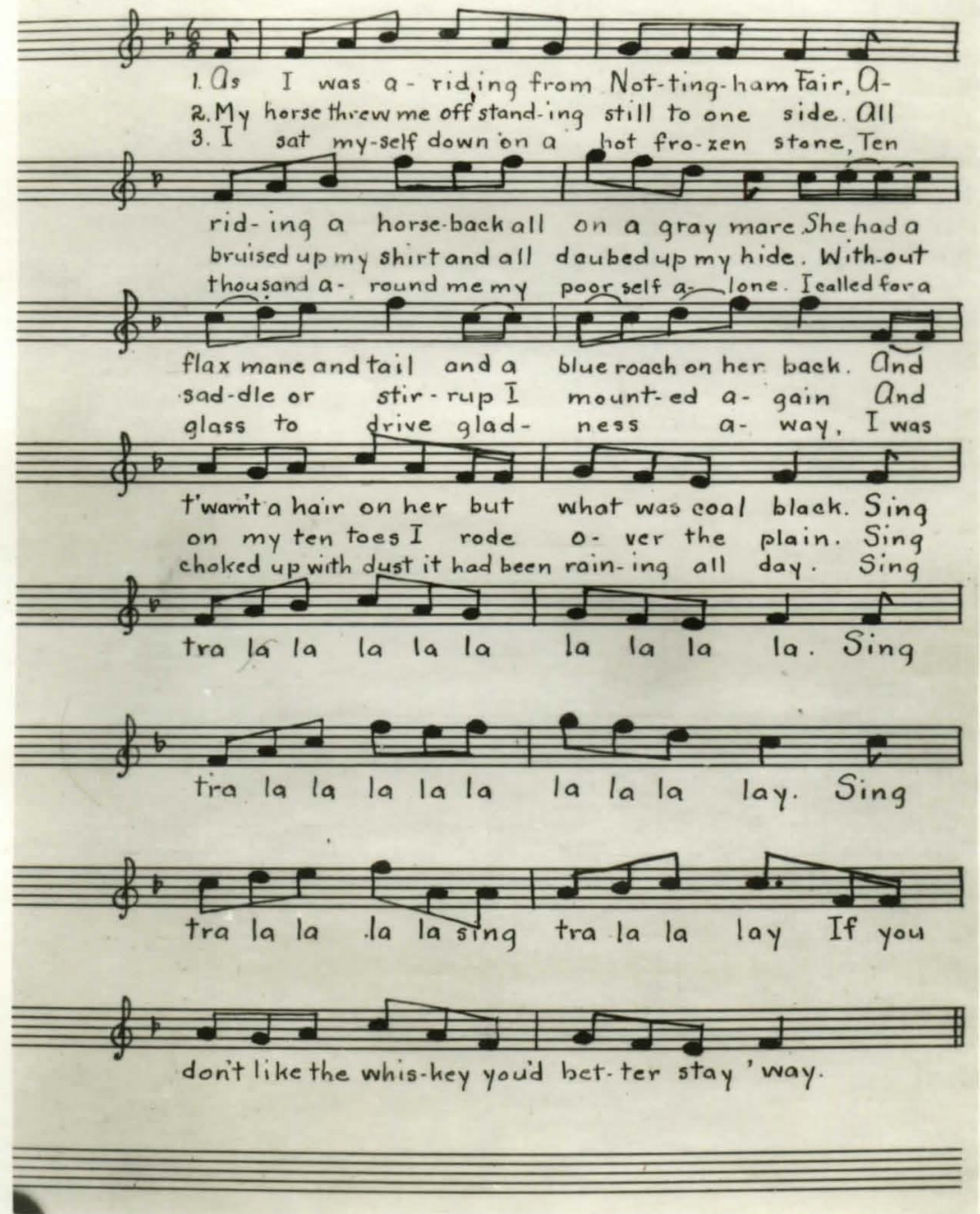


The murder of Pearl Bryan

Pearl was a girl from Greencastle, Indlana, and often visited friends in Cincinnati. One evening Alonzo Jackson and a man named Walling called on Pearl. The men were dental students in the University of Cincinnats.

A cab was hired to drive the two men and Pearl to Fort Thomes, Kentucky, across the river from Cincinnati. The colored driver later testified that when the two men helped Pearl from the cab she seemed to be in a stupor.

The girl's body was found the next day on the Leck farm near Fort Thomas, not far from the Newport Reservoir; however, her head was missing.

Upon the arrest of the men, people hoped to recover the missing part. The men, however, refused to tell where 1t was. It was thought the head might be in the reservolr, and while thousands of spectators looked on, the reservolr was drained, but it was not there.

Although the head was never found, the ldentity of the body was established by the shoes the victim wore. They wore made by a Cincinnati manufacturer and sold to a store in Connersville, Indiana, which in turn sold them to Poarl.

Although they were friends before the trial, Jacks on and Waling became bitter enemies, each accusing the other. They were both convicted and sentenced to be hanged; still 
thoy stubbornly refused to tell where the hoad was.

One of the murderers had in his childhood given his foster parents mach difficulty; he went to the scaffold in the court house yord in Newport sing ing a song of his own composing, "The Other Half Will Never Be Known," referring to the missing part.

That was some years ago, and by the way, every man that sat in the fury and convicted those two has died a tragic death, met with an accident, or had some stroke of 1ll-fortune resulting in a horrible death, so they say.

In 1936 another solution was given for the whereabouts of Pearl's head. Near a dilapidated two-story house off Waterworks Road about one-fourth mile from the Newport Reservoir, two little boys found a skull, a humen one. Immediate investigation disclosed that the mysterious old woman who lived in the house had stray dogs which she had befriended. The place was filthy, more bones were found; however, they proved to be the bones of animals. No trace was found of the old woman.

But there was the muman skull. Whose was it then? Many said it could belong only to Pearl Bryan and that the mystery was solved. Others say, "Is it?"

This tragedy has been the theme of many ballads. 
Mrs. Charles Ruck

R. R. No. 2, Jeffersonville, Indiana

35

German

Pearl Bryan

Now ladies if you listen a story I'll relate

That happened near Fort Thomes in old Kentucky state. Twas late in January this awful deed was done,

By Jackson and by Whalling, how cold their blood did run.

How bold these cruel villains to do this awful deed, To ride away Pearl Bryan when she to them did plead. The driver telis the story of how Pearl Bryan did moan

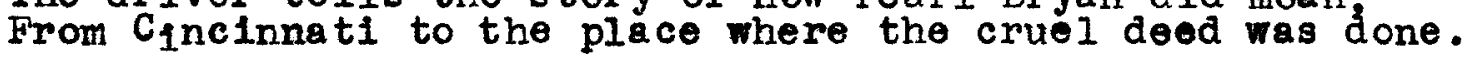

But little did Pearl's parents think when she left a happy home,

That their darling daughter would noier return again.

We know her dear old parents their fortunes they would give,

If Pearl could just return home, a happy life to Iive.

The driver was the only one could tell the awful fate, of poor Pearl far away from home in old Kentucky state. A farmer passing by next dey her lifeless form he found, A-lying on the cold spot where her blood had stained the spot.

Pearl Bryan left her parents on a dark and gloomy day, She went to meet the viliains in a spot not far away. She thought it was the lover's hand that she could trust each day,

Alas! It was the lover's hand that took her life away.

Young ladies now take warning, young men are so unjust, It may be your best lover, but you know not whom to trust, Pearl died away from home out in that lonely spot, Take heed, take heed, believe this girls, don't let this bo your lot. 


\section{"Jeslous Love"}

Down by a weeping willow

Where the violets fade and bloom There sloeps a fair young malden So silent in her tomb.

She died not broken hoarted Nor Illness did she have

But by a fealous lover

Who her dear life would have.

One eve the moon shone brightly

And gently fell the dew

Into a lonely cottage

Where her jealous lover knew.

Come, love, and let us wander

Down through these woods so gay,

Come, love, and let us wander

And name our wodding day.

Edward, these woods are so lonely

I do not care to roam,

Besldes, I am tired and woary

And I pray you take me home.

Into these woods I have you

From me you cannot fly

No power on earth can save you

So here now you must die.

Down on her knees before him

She prayed that God might spare her life,

But deep in her white bosom

He plunged that dreadful knife.

Edward, I will forglve you

Were her last and dying words,

I never have betrayed you,

So I close my ejes in death.

Mrs. Rose Logsdon

714 Montgomery Avenue

Jeffersonvilie, Indiana

62 (sixty-two)

Irish 
Informant.... Mrs. Lula Dunn

Address......113 Virginia Avenue

Age.........45

Nationality.Irish

Poarl Bryan

Deep in yonder valley,

Where the flowers fade in bloom, Lives there Pearl Bryan's body,

In a cold and silent tomb.

She died not broken hearted

Sickness never o'er her falied, But an innocent soul has parted, From a home she loved so well.

The moon was shining brightly, The stars were shining too, Up to her cottage window, A jealous lover drew.

Como, Pearl, let's take a ramble, Down o'or the meadows gay, Where no one can disturb us, We'll name our wedding day.

The way soems dark and dreary, And I'm afrald to stay, of rambling I am weary, Then let's retrace our way.

Retrace your way, no never, These roods you'il roam no more, So b1d farewell, Pearl Bryan, To your perents, friend, and home.

Down on her knees before hlm, Pleading for her life, What have I done, Scott Jackson, For you to take my life?

You know I've always loved you, And would have been your wife, Deep down in her snow whito bosom, He plunged the fatel lmife. 
The students have found five versions of this song. They differ greatly as to the number of stanzas from those recorded by Henry in Folk Songs of the Sou thern Highland.

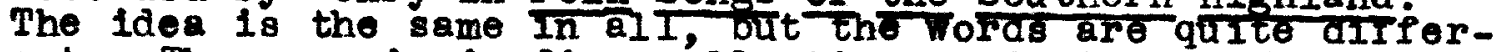
ont. The song is in five collections made in the United States.

\section{Ilttlo Rosemood Casket}

There's a little Rose Bud Casket, Sitting on the marble stand. There's a package of love letters, Writton by my sweetheart's hands.

Go and bring them to me, brother, Come and sit beside my bed. Lay your head upon my pillow, By my aching head most dead.

Read them gently o'er to me, brother, Read them till I fall asleep. For the sleep will wake with Justice, Dearest brother, do not weop.

Last Sunday I saw him riding, With a lady by his side. And I thought I heard him tell her, That soon she would be his bride.

I see him coming up the pathway, Brother, meet him at the door, Tell him I will forgive him, If he courts that girl no more.

When I'm dead and in my coffin, And my friends are gathered round, And my narrow bed is ready, Lay me in the church yard ground. 


\section{"The Little Rose Wood Casket"}

In the little rose wood casket That is resting on the stand

Is a package of old letters

Written by a cherished hand.

W111 you go and get them, sister,

Will you read them o'er to mo

For oft times I've tried to read them

But for tears I could not seo.

Now I'm ready now, dear sister,

Come and sit down on my bod

And place gentiy to your bosom

Th1s poor throbbing aching head.

While I listen to you read them

I will gently fall asleop,

Fali asleep to wake with Jesus

Oh, dear sister, do not woop.

Tell him that I'll nover blame him, That one unkind word was spoke Tell, oh, tell him, sister, tell him That my heart in coldness broke.

Mrs. Claude Elliott $214 \mathrm{~W}$. Maple Streot 40 (forty)

$\operatorname{Ir} 1 \mathrm{sh}$ 
Informant....L. T. Williams

Age.........40

Nat Ionality...English

The Rosewood Casket

In a little rosewood casket

on a simple rustic stand

Is a package of love letters

Written by a cherished hand.

W1Il you go and get them, sister,

Will you read them o'er to mo

For oft times I've tried to read them

But for tears I coula not see.

You have finlahed now, dear sister,

Come sit down upon my bed

And press gently to your bosom

This poor, throbbing, aching head.

Tell him that I never blamed him

Tho ho proved untrue to me,

Tell, oh, tell him, sister, tell him

That I bid this world adiou.

By Helen Scott

English VI 


\section{A Ilttle Rosewood Caskot}

In a little rose wood casket Lying on a marble stand There's a package of old letters Written by my true love's hand.

Go and bring thom to mo, brother, Come and sit upon my bed

While your head upon my pillow aching heart is dead.

Read them to me, brother, Read unt 11 I fall asleop

Unt1l I wake in heaven

Dear brother, do not weep.

Yesterday I saw him walking

With another by his side,

And I thought I heard him tell her

She could never be his bride.

Tell him I do not blame him

That not one unkind word was spoke

Tell him, brothor, tell him

That my heart for him it broke. 
Ilttle Rosewood Casket

There's a little Rosewood Casket, That is all the world to me;

And it holds my darling's picture,

Whom I loved so tenderiy;

Bring my sweetheart's photo to me,

Let me kiss its faded hue;

While I gaze into her blue eyes,

Oh, so fond and oh, so true.

When. I die lay me beslde her.

Place her picture at my head;

Then my soul will rest so peaceful,

In my weary, dreary, bed.

There's a Ifttle Rosewood Casket

That is all the world to me;

For 1t holds my darling's picture,

I love her so tenderly. 
In West Virginia "Hy Little Mohea" is found under the tities "Pretty Maumee," "The Little Maumee," and "The Protty Maumeo." This has wide circulation. The students in Jolfersonville found two versions different from those recorded by Cox or Henry.

\section{THE IITTLE MOHEE}

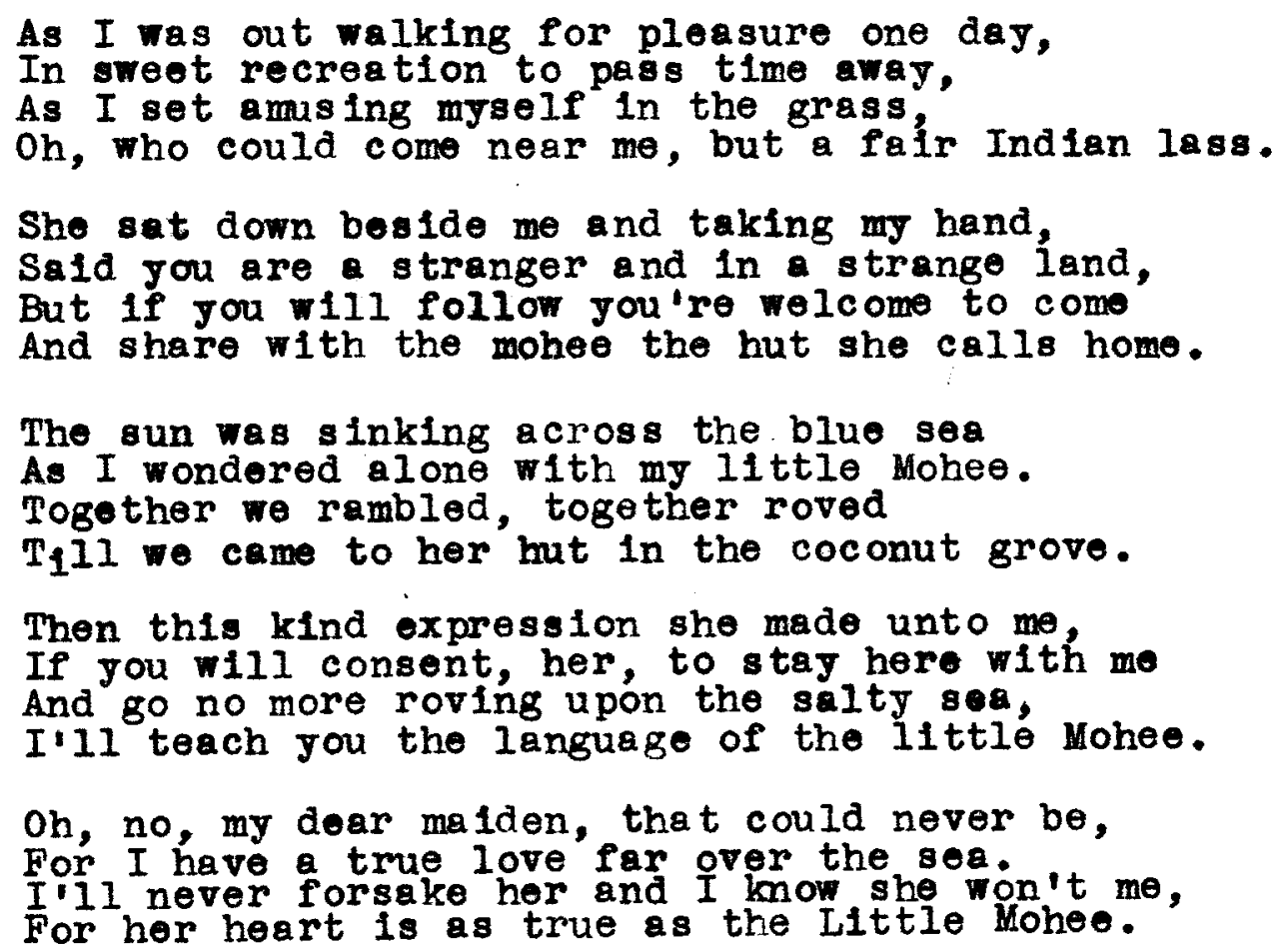

'Twas early one morning in May That to this fair maiden these words I did say: I'm going to leave you, so farewell, my dear, Hy ship's sails are spreading and home I mat steor.

The last time I saw her she stood on the sand, And as my boat passed her she waved me her hand, saying when you get home to the girl that you love, Just think of the Mohee in the coconut grove. And when I had landed on my own native shore
With friends and relations gathered round me once more, 
I gazed all about me but none could I see That was fit to compere with my little Moheo.

The girl I had trusted proved untrue to me So I'll turn my courso backward far over the blue sea. I'II turn the course backward, from this land I will fiee And go spend my days with the little Mohee.

Helen Scott 
Informant......Mrs . Alta Stewart

Address........1101 E. Market st.

Age

Nationaitity...

My Little Mohea

As I was out walking one morning in May,

With soft recollections as the day passed away, And as I reclined myself down in the shade, When who should I spy there but a young Indian mald.

She came up close by me and gently gave me her hand, And sayling you look like a stranger, not one of our' land But if you will consent, sir, nor move to roam, Wo w1ll live here in my snug little home.

No, no, dearest maiden, that never can be, For I have a sweetheart in my own country. I'll never forsake her, and I know she won't me, Her heart is as true as my little Mohea.

I am going to leave you, so farewell, dear, on the first ship set sailing at home I'll a ppear.

She came up close by me, gently gave me her hand and saying When you get there to the one that jou love, Don't forget your little Mohea in the cocoanut grove.

Once more I have landed upon the seashore, Kind friends and relations gather around me once more. But as they gather round me, there is none I can seo, That I would compare with my little Mohea. 
Folk songs are the outlet of the many and varied enotions of the folk. Superstitions is their attitude toward the manifestations of God, nature, or any other force which they cald not understand. Restricted by ignorance, the primitive mind invented for itself causes for these mysterious manifestations. Many of their superstitions persist to this day, particularly in remote rural communties and other localities where education has been slow to take root.

Superstitions of the Folk. It is pleasant and encouraging to look back over the rough road the human race has traveled, and to reflect upon 1 ts triumphs. It looks as if the day before jesterday men were ignorant brutes, yesterday they were superstitious chllaren, today they are intelligent individuals, and tomorrow--?

Men are the children of their experiences -- racial experienees as well as personal, spiritual experiences as well as physical -- so they may well pause for a moment in their achievements, to Iisten to the echoes of ancient enchantment.

The origin of many superstitious bellefs and practices is found in man's effort to explain nature, and in an attempt to satisfy angry gods and make conditions better.

Ignorance is the main cause for superstition. Early man's intelligence suggested that every manifestation of 
nature was the work of a spirit or devil. Fear has been an important factor and when danger was near, man sought a way of escape; consequently a superstition was born. Practically all nations have certain customs, rites, and usages, that have their beginning in superstitions. A very fine line is draw between religion and superstition, depending on one's point of view; what is faith to one people may be folly to another. Many superstitions were born in the conilict between two sects. Some of them were created by a too literal or perhaps a false, interpretation of the Bible.

Some Christians think Friday is a bad day to begin an important work, because Christ was crucified on that day. The unhappy ending of Christ's Last Supper brought about the fear of having thirteen seated at the table.

Many superstitions had their initiation in commands laid down to teach lessons. A lazy father issued a command that his daughter shall not disturb his slumbers by singing before breakfast; the command later became the papular superstition that it is unlucky to sing before breakfast. The folk of any nation lay down certain laws of "do and don 't" which have been based upon cause and effect. Many of these laws may be traced to ancient cult practices. Some belleve that they are the last remants of ancient myths whose significance has long been forgotten. "To the folklorist the whole body of superstitions of a folk 
is of interest in understanding its mental life, and in observing in this true reflection the exact character and living conditions of the folk. It is for the doctor to determine if any of the cures suggested are really effective; for the priest or preacher to determine if any of the religious superstitions are in accordance with their religions; and for the psychlatrist to determine if any of the explanations of natural phenomena colncide with theorites accepted today. 15 The bellef in falries and other supernatural beings is universal, not only amone children but amone grown people as well, and many a quaint and interesting lezend has been spun about these fascinating conceptions. Falry lore comprises the greater part of the books for young children, and without fairy tales their lives wald be barren indeed. So, also, have many superstitions grown up about fairies, and it seems they are belleved in by folk that are intelligent as well as by those that are ignorant.

Fairies are supposed to be supermatural beings, human in form but very often diminutive, with superior powers for good or evil. They have the power of invisibility, but can become visible when they wish. They are often invoked for aid, but are never worshipped as were the goddesses of the

\section{Ralph steele Boggs, Folklore} (Chapel Hill, N. C.: University of North Carolina Extension Bulletin), p. 34 
pagan world. They enter the habitations of mortals and spread their gifts. Sometimes they do mischief. It is well to keep in the good graces of the fairies.

The Hindoos, says Astra Cielo, 16 believe in a kind of fairy that they call "Acvins." Persians believe in Peris, delicate, ethereal females who while not immortal, live very long. The Arabian "Jinns" are falries of a more austere kind. They are males who can do great damage if offended. The Jews believed in Shedin, a specles of fairy that was supposed to have been the of spring of Adam. The Greeks and Romans believed in dryads, naiads, fauns, aatyrs. Fata Morgana is the Italian conception of a fairy, the personification of Fortune. In France, fairies have different names and characteristics. There are "follets" who are always invisible but whose voices are often heard. They believe in rees, lukins and coblins. Scandinavians believe in elves, playful, malicious beings that are up to all sorts of mischief. Teutonic races have their fairies, trolls, gnomes, dwarfs, who do all manner of mischief. The Irish are preat believers in fairies and their literature is fllled with tales of the doings of the little people. Their superstitions conceming them would fill several volumes. Brownies and kelpies are

\footnotetext{
16 Astra Cielo, signs, Omens and Superstitions (New York: George Suil $\overline{\mathrm{J}}$ and Company 1918) pp. 68-75
} 
the sçotch brand of fairies. English have their fairies, hobgoblins, Robin Goodfellow, Puck, and other well-knowm figures. Shake speare as embled them in one large clan, with Oberon as the king and Titania as their queen.

Some of the better-known superstitions concerning fairies are the following:

A mole or other small defect on a person is supposed to be caused by a falry nipping him before birth.

A matted lock near the neck of a sleeping child is called an elflock and is the deed of a mischlevous fairy. Four-leaved clover usually marks the spot where fairies congregate and bring good luck.

Circles often found in the grass indicate the place where the fairies dance. To sit in such a circle with one of the opposite sex, is sure to bring about a marriage. When a child is lucky it is a sure proof that a fairy godmother stood at its cradle at its birth.

A fairy entering a dairy spoils the cream. Lumbago, epilipsy, and fits are supposed to be caused by a shot from a malignant fairy.

The belief in witches is very old. At times in the history of mankind it has become epidemic and has done untold damage. In the seventeenth century thousands of old women were burned at the stake for their supposed intercourse with the devil. Doctors and juiges, as well as ignorant people 
believed this nonsense. The witch was supposed to be a woman who had sold her soul to the devil, and frequented the Devil's Sabbath, riding thither on a broomstick.

Like all forms of folklore, bellefs concerning witches are found in all parts of the world, and have existed since earliest times. Originaliy they grew out of that part of nature which was not favorable to man's well-being; to the elaboration of ideas concerning the spirit world; and to the extension oi ideas of the voluntary action of evil forces to the will of man. They function for the Devil as agents of destruction. They, with the ir master, destroy man and his property by sickness, disease, and death. They rejoice in their evil deeds, for which they seek some bare pretext. They seek vengeance for petty wrongs done to themselves or lend their evil services to others to have accounts or grievances to settle. The head of their evil company gives them control over physical elements. They can assume any shape, fly, pass through a keyhole, and may even command storms. Hystery, darkness, and secrecy surround their activities. Playing upon fear and Ignorance concerning the dead and the mysterious workings of nature, these forces gain credit. One who has fearful powers for setting the forces of destruction at work must also be able to stop them. Thus the witch becomes a doctor and cures by removing the evil spirit. One who has control over unseen forces must also control time and be able 
to see into the future. Thus the witch becomes a seer. Activities that coincide readily with the nature of a witch are those of a vampire or bloodsucker, and those of a ghoul, or corpse eater.

When horses break out in a sweat in the stable, it is belioved that a witch has been riding them.

When a horse's mane is tangled, a witch is supposed to have tied the lnot to use as a stirrup.

Shoulder bonds of sheep are called "hag-bones" because witches are belleved to ride on them.

Egg shells must be broken and not left to lie about the house, or they may be used by witches as boats.

To prevent a witch from injuring a person, he must make an imase of wood of the witch and stick it full of pins. This will cause the witch to become impotent and die.

Wearing the left stocking inside out, horse shoes, spittle, hogstones, etc., are effective antidotes to a witch's power. The sign of the cross also prevents evil.

Dr. Thomas 17 in his book on Kentuclry Superstitions explains superstitions in this way:

The origin of all superstition may probably be traced to the desire of mankind to propitiate fate, to avert evil, and to dispel the mystery

17 Daniel L. and Lucy B. Thomas, Kentucky Superstitions (Princeton: Princeton University Press, 1920) 
of Iife and of the universe. Primitive man, in his fear of evils that he did not understand, sought to avoid disaster by any means thathe could find. In his ignorance of 10 ic, he often accepted a coincidence as a cause.

Francis Bacon well says:

First, that men mark when they hit, and never when they miss; as they do, generally, also of draams. The second is, that probable conjectures, or obscure traditions, many times turn themselves into prophecies; while the nature of man, which covets the divination, thinks it no peril to foretell that which indeed they do but collect. - : The third and last (which is the great one) is, that almost all of them, being infinite in number have been impostors, and, by idle and crafty brains, nearly continued and figured, after the event had past.

The reasons for the survival of superstitions from a more primitive age into this age are that the people are slow to surrender beliefs that they have inherited, that many of them are still ignorant and timorous, and that in spite of the explanations, of both science and religion they continue to find Iife and the universe largely inexplicable. The most common superstitions mentioned by those ensaged in research were the ones about Ffiday, the number thirteen, the dropping of a knife, a fork, or a spoon, the plcking up of a pin, the first sight of the new noon, the breaking of a mirror, the presenting of a knife to a friend, the potency of the horseshoe, the burning of the ear, the passing of two companions on the opposite sides of a post, the howl of a dog, the presence of a bird in the house, the opening of an umbrella in the house, and the turning back 
after one has started.

If these various instances are analyzed, it strikes one, that for the most part, there are dire effects from the occurences, as each seems to come from a lack of preparedness or forethought. Human frallty therefore places the blame bejond human jurisdiction.

17. The writer's subject-matter for the teacher is nerely sugpestive, and must be supplemented hy wide reading on the surject. 
Superstitions Found in Bono

By Leah Neideffer

For telling your fortune by the yarrow leaves. Pick two leaves of yarrow and place them under your pillow. Before going to sleep, stand on your kmees and bow three times to the yarrow leaves saying "Good evening to this yarrow. Good evening thrice to theo may I this night, dream of who my true love is to be--the color of his hair--the clothes he shall wear--the day he is to wed me." Do this three nights and the third time you will dream of your future husbend. And to tell your fortune by the new moon look at it and name your choice and say "Now moon-true moon, bright and light. Won't you be my true love tonlght. Face to me, sure to be, side to me, longing to bo. Back never to be." When you see the one you will marry if the side or back is to you then no such luck.

For charming off warts. Rub a greasy dish rag over your warts and bury the rag where no one sees you. When the rag rots the warts will leave. Or pick the warts with a grain of corn until they bleed. Call a chicken and throw the corn over your left shoulder being sure not to peep.

Another superstition. When a nelghbor called whom you know was bewitching you and causing you trouble, as soon as he leaves heat a horseshoe nail red hot and drive into the door step. This keeps him from bewltching you by drawing away 
the witch.

When the butter won't come heat an iron and drop it into the churn. The heat will drive the witch away. Mike Wilfong an old man I knew believed this to be true. And one time when he was churning tried the hot iron. of course the heat cause the butter to separate. But next time he sar the girl he hoped to marry she had a burned hand. He thought she was the witch and was afraid of her and always swore she was a witch. 
Superstitions

Information: Urs. Claude Elliott

Address: 214 West Haple Street, Jeffersonville, Indlana Ago: 40

Nationality: Irish

If your left hand itches it is a sign you are going to receive money.

If it rains on Easter Sunday it 111 rain the next seven Sundays after Easter.

If there is a death on your street there will be three within a year.

If you drop your dish towel it is a sign someone's coming dirtier than jou are.

It is bad luck to pick up a comb when you drop 1t.

If you drop a knife it is a sign a girl friend is coming; if it is a fork a boy friend is coming; or if it is a spoon a child is coming.

To find a four leaf clover means good-luck is coming your way.

If your right hand itches it is a sign you are going to shake hands with old friends.

If you break a mirror you are to have seven years of bad luck.

It is bad luck to go in one door and out another. 
If you k111 a spider it $111 \mathrm{rain}$.

If your foot itches on the bottom, you will waik on strange land. 
Informant....."Red" Forgus on

\section{River Superstitions}

This story was told to me by a man who got the body of a high school boy in 1938. The Ohio River had been dragged for two days and nights for the body, but no luck. "Red" Ferguson thought he would try an old river superstition that he had heard all of his life. This is how he told it to me:

"I went to the boy's grandmother and asked her for the shirt that he last wore. I told her what I was going to do. I went down to the river, spread the shirt on the water where the boy was last seen. The shirt floated down stream a fow feet, stopped, twirled, and floated on a few more foet and sank. I had another follow helping me drag where the shirt twirled, and some more men dragging where it sank. I found the body just where the shirt stopped and twirled, and the shirt was about 15 feet from the body."

This man told me that if you put a silver coin on a loaf of bread, it works the same way. The perspiration on the shirt is drawn to the body, but he doesn't know what draws the loaf of bread. 
Informant: Patrick Bane

Address : 825 Welnut Streot

Jeffersonvilie, Indiana

Age: 76 years

Nationality: Irish

\section{FAIRY SONG}

On Novomber ist, the fairies moved to new quarters in the village of Oran More on the county of Galway. It happened this way. While passing a hill on this November night a boy with a hump on his back heard volces singing, --

"Saturday, Sunday, and Monday," was the fairy song, so the boy sang too, but he sang, "Saturday, Sunday, Monday, and Thesdey."

He heard a voice saying, "Who is improving on my song?" so he took the boy to fairyland.

"I see, lad, you have a hump on your back. I will take it off," said the fairy as he sent the boy back home, and his folks didn't know him he looked so fine.

It happened that in this same village there lived a rich family that had a boy with a hump on his back. When he heard about the fairy song, he thought he would go to the fairies. So the following November night he was pasing a very long hill when he heard the fairles singing "Saturday, Sunday, Monday, and Tuesday," so he started to sing "Saturday, Sund ay, Monday, Thesday," and the boy added "Wednesday." 
Then he heard a volce sey, "Who is apoiling my song?" so they took the boy in. The King Fairy sald, "You have a hump on your back so I w111 put another hump on for spoiling my song." This happened during November 1880 in Galway County, Ireland.

Contributed by Maurice Milier Age 16 jears English V Jeffers onvilie High School 
Informant.....

Address........ Ohio Avenue, Jeffersonville

Age..........24

Nationality

The Figure of Christ

There was young girl and she was very religious. One night she saw Christ in a dream. He told her to go out into the front yard and take a picture of a little tree, and there would be the figure of Christ. The next morning she told her family about the dream, but they all laughed at her, telling her it was a funny dream. But she took the picture of the tree and when she had the film developed, there was the picture of Christ. It was snowing when she took the picture and she thinks the snow formed the figure of Christ.

Most people think it was her strong falth that mado her take the picture. 
Informant: Philip Higdon

Address: 422 Indiane Avenue

Jeffersonvilie, Indiana

Age: 53 years

Nationality: German

\section{A WARNING}

About forty-eight years ago, my father told his father that the building would fall in that night. About three o'clock in the morning, his father aroke by a touch on the cheek by a pigeon but of course there wasn't any plegon in the house. The first thing he thought of was of my father's telling him that the brick wall would fall. He told everyone to get out in the kitchen because he sald it was going to fall. He went back and got the foather bed and as the door closed, the brick wall fell in.

Contributed by David Higdon Age 16 years English VI Jeffersonville High School 
Informant....Dr. Laws on

Address.....628 Harrison Avenue

Age..........86

Na tionailty..Amorican

\section{Folk Lore}

Aunt Kizzy was a pioneer darky who had power with the Lord. On the last Sunday of her life, she attended a church meoting. While there she was enlivened by a heavenly light, she jumped to her feet clapped her hands and shouted, "I hate the devil, I love the Lord, I want to die on my knees." That same evening she was heard by a nelghbor praying to let hor die on her kneos. Then she stopped praying, and out of curiosity he peeped in at her window. She remalned motionless so long he feared the end had truly come. He went and summoned others, and they entered and found that he had spoken the truth. God agein had answered her prayer. He had taken her on her knees.

By John Brown English VI 
Informant...... E. Poindexter

Address....... High Street, Jef fers onvilie, Indiana.

Age.........86 jears

Years in Ind Ians...86

Nationality . .German

The Logend of the "Unfertile Spot"

When my groat-grandfather settled on the country around where the Union Methodist now is there was peculiar spot of land in the middle of a dense forest where nothing grew. The circle was about thirty foet in diameter and was surrounded by tall trees. great-grandeather was curious about this and in some way heard this story: Wany years before the white men came there were two rivel Indian Tribes inhabiting this section. One day while one of the chief's sons was killed by members of the rival tribes. His blood wes spattered over the ground, and when his father saw this he mede a curse saying that no living thing should grow on this ground. The trees disappeared and to this day nothing grows in that spot.

Contributor--Charles Polndexter Age -15 years Grade--10A 


\section{CHA PTER V}

CONCLUSIONS

The untt of work on folklore for secondary schools with a sampling of Hoosier folklore has been prepared and presented to the Junior classes in the Jeffersonville Senior High School, Jeffersonville, Indiana.

The writer consulted such authorities as Thomas H. Briggs, 1 Henry Harap, 2 Herbert B. Bruner, 3 and wilbur Hatfield 4 on curriculum construction. The material for the study was the result of the writer.s and students research. The content was organized under four separate headings; namely, "The Origin of Folklore," "The Folk Tale," "The Folk Song," and "Superstitions of the Folk."

The methods used in teaching the unit were many. There was class discussion, orienting the students in the rich and varied content of the many types of folklore, there

1 Thomas H. Briggs, Functions of Secondary Education (Department of Secondary School Principals of the National Education Association, 1938), pp. 5-8

2 Henry Harap, The Technique of Curriculum Making (New York: The Macmilian Co. 1928), p. 315

3 Herbert B. Bruner, Compton's Pictured Teaching Units (Chicago: 5 . E. Compt on \& Co. 1933), No. 1, 2, 3, 4.

4 Wilbur Hatfield, An Experience Curriculum in English (National Council of Teachers of English), pp. 86-88 
were projects and problems involving the students' experiences in and out of school.

The samples of Hoosier folklore show that the students were able to collect the lore, classify, and report it in a correct form.

The letters from the superintendent and teachers in Jeffersonville High School give their opinions of the reaction of the students toward this study of folklore.

The writer has been asked to talk on "Hoosier Folklore" at the Jeffersonville Business and Professional Women's Club and at the Jeffersonville Study Club. She feels that the pupils, the school, and community are interested, and they have co-operated enthusiastically in furthering the study of Indlans folklore.

There is st1ll much to be done; however, there are some tangible evidences of the study. Two books on Hoosier folklore have been compiled by the students. These books contain myths, legends, folk tales, folk songs, superstitions, and place names, as well as origins of the students' surnames and given names. These books will become the property of the high school library and the public library. Because of the students' requests for books needed in their research work on this subject, the librarian has purchased many new books 
and has offered to buy others as the need arises.

The teaching of folklore in Joffersonville High School may lead to a closer interest, understanding, and appreciation of many of the subjects in the curriculum. The students onjoyed the language experience in studying name origins. This interest may lead to a course in general language, which furnishes a background for language study, a study of English in its relations to other languages, and etymology. The course usually includes the story of the development of language in general, and the origin of English and its relation to other languages; some information as to the history and etymology of the English words, and the relation between them and the words of other languages; a foretaste of the study of forelgn language, which gives pupils what has been termed a language sense; and a general background of the national customs, home Iffe, civilization, literature, and history of Rome, Germany, France, and Spain.

Folklore is an effective approach to Forld History, which is now being taught in the secondary schools. The customs of the Indiana folk, brought from the 0ld World, are shown in the play-party. This was a distinctive form of entertalnment in early rural sections of the state, representing the customs of the Scotch, Irish, German, and English as they reveal in play their national characteristics. The 
Importance of these social gatherings can scarcely be overrated, because the occasions for coming together of the people were so few.

There are other possibilities for future study. These types of folklore--proverbs, riddles, games, and plays--may be considered and developed in the future.

Through this study the writer feels that she has broadened her own culture. It has been a satisfaction for her to go into the highways and byways of the state and collect the lore which has renewed her pride in her state's holdings in potential literature, in its life and background. She has been something of a missionary in making the people whom she met in this connection conscicus of what they had to contribute, and in interesting them in finding further 1ore. Many of her students have the zeal of proselytes and are continuing to add to their store. These factors will no doubt contribute to the enrichment of their experiences in the plans they are formulating for a folk festival. In this they expect to demonstrate the traditions and customs of their community and state at a time that the state's atmosphere is most Hoosier-like--

"When the frost is on the punkin

An" the fodder's in the shock." 
BIBLIOGRAPHY

A. BOOKS

Anders on, Hans, Fairy Tales

Chlcago:. .. Donahue and Company, 1926.

Auslander, Joseph, Winged Horse

New York: Doublecty, $\frac{\text { Dora }}{10}$ and Company, 1938.

Baring-Gould, S., Curious Myths of the Middle Ages London: Rivington, 1881. Board Charles, and Bagley, W. C., Our old World Background

Bobbit, Frankin, How To lake a Curriculum Now York: Houghton HIflin Company, 1924

Boggs Ralph Steol, Folklore Bulletin, 1929.

Bowman, W' B. The Story of Surnames

Briggs, R., Riddies in Rhrme Washburñ and Thome $3,1927$.

Briggs, Thomas H., Secondary Education New York: The Macmillan Compeny, 1933.

Bulfinch, Thomas, Bulfinch's Mythology Now' York: Grossett and Danlap, 1913.

Canby, Opdycke, Gillum, High School English How York: The Macmilian Compeny, 1934.

Carpenter, Frances, Tales of a Basque Grandmother Now York: The Junior It terery Guild, 1930.

Caswe11, and Campbe11, Curriculum Development American Book Company, 1936.

Chamberlain, Essie, Essays Old and New Ch1cago: Grossott and Dun1ap, 1938.

Charters, W. W., Curriculum Construction Now York: The Macmillan Company, 1929. 


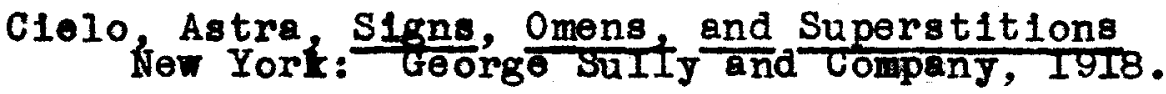

Colum, Padraic, The Road Round

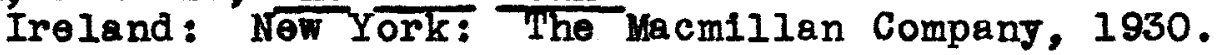

Cowper, Curc1, The Indian Orchard. A Traditional Story of Terre Haute. Indiana state Public Library.

Cox, George W., An Introduction to the Sciences of Comparative Mrthology and Folkiore. Kegan, French and Company, 1883.

Cox, John Harrington, Folk-Songs of the South Cambridge: Harvara University Pross, 1925.

Cox, Philip, W. L., Curriculum Adfustment in the Secondary School: Philadelphia: J. B. Lippincott Company, 1925.

Dane, G. E., Once There Wes and Was Not New York: The Junior Literary Gulid, 1931.

Douglas, Harl R., Secondary Education for Youth in Modern America. Washington, D. C.: American Council on Education, 1937.

Draper, Bdgar M., Principles and Techniques of Gurriculum Eaking. New York: D. AppIe Eon-Century Company, 1936.

Dunn, Piatt, Jacob, Indian Stories Indiana polis: Sentinel Printing Company, 1908.

Eggleston, Edward, The Hoosier School Master Hew York: Grossett and Dunlap, 1923.

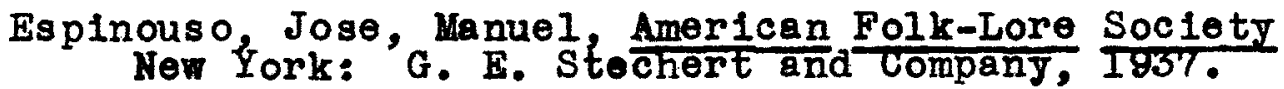

Fiske, John, Myths and Mythmakers New York: Houghton Miffin and Company, 1900.

Frazer, J. G., Folklore in the 0ld Testement Now York: Macmilian, 1919.

Goldmark, Josephine, Democracy in Denmark Washington, D. C.: National Home LIbrary Association, 1936.

Gummere, F. B., Folk Song Warner's Library of the World's Best Literature.

Harris, J. C., Nights with Uncle Remus Houghton. Various editions. 
Hart, Joseph K., Light From the North

Now York: Henry Holt and Company, 1926.

Henry, Mollinger, Edward, Folk Songs from the Southern Highland New York: J. J. Aust In PubIIshe r. 1938 .

Hollman, A. H., The Folk High School

Washington, D. C.: National Home Library Foundation, 1936

Jack and the Bean Stalk

Encyclopedia Amerlcana, Vol. 15, p. 476

Johns on \& Scott, Anthology of Children's Literature

Chicago: Houghton uffin and Company

Kelley, James P., Workmanship in Words

Boston: Littie Brown and Company, 1916

Kittredge, George, Lyman, Witcheraft in old New England Harvard, 1929.

Koch, F. H., Folk-Drama American Chapel HIII, N. C.: University of North Carolina Press, 1922.

Lang, Andrew, Arabian Nights Falry Tales Now York: J. H. Sears and Company.

Lang, Andrew, Custom and Myth New York: Harper Brothers, 1885.

Lang, Andrew, The Blue Fairy Book

Lang, Andrew, The Yellow Fairy Book

Lomax, John Avery, American Ballads and Folksongs Now York: Macmillan Company, 1934.

Lomex, John Avery, Songs and Other Frontier Ballads New York: Macmilian Company, 1929

McGraw, H. W., Prose and Poetry for Appreciation Chicago: The L. W. Singer Company, 1935.

Morrison, Henry C., Basic Principles in Education Now York: Houghton Mifflin Company, 1934.

Murray, Amy, Father Allan's Island . Hew York: Harcourt, Brace and Howe, 1920. 
Noodham, M. M., Folk Festival

New York: B. W. Huebach, 1912.

Nowelle, Lee, The Hoosier Schoolmester - Drama Evanston: Row Peters on and Company, 1953

Nowlin, $C_{l}$ ifford $H_{.}$, The Story Teller and His Pack Springfield: Milton Bradiey and Company, 1929.

Oberndorfer, Marx, A Century of Progress in Amerlcan Song Ch1cago: Hail and Mccreary Company, I933.

O'Ne1ll, Elizabeth, Storles That Words Tell Us London: T. C. and E. C. Jack, Ltd.

Reed, Barl H., The Silver Arron Chicago:' KoIIIJ and Le日, 1926.

Ryder A. W.: The Panchatantra

Sabin, Frances E., Classical Myths That Live Today Chicago: Silver Burdette and Company, 1927.

Sandburg, Carl, The American Songbag

New York: Harcourt Brace and Company, 1927.

Sharp, Cecil James, One Hundred English Folk Songs New York: C. H. Dilson and Company, 1912.

Shubert, Marie, Minute Myths and Legends

Now York: Grosset and Dunlap, 1934.

The Standard Dictionary of Facts

New York: The Frontier Press Company, 1925.

Stevens on, Augusta, Romantic Indiana

Indianapolis: Bobbs Merrill Company, 1916.

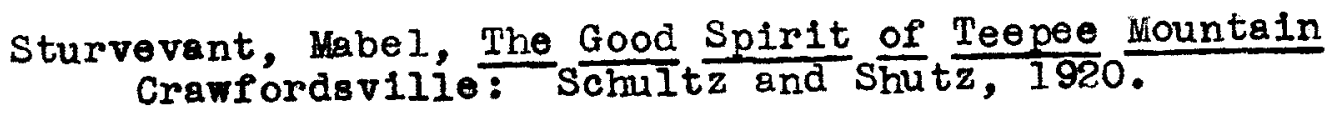

Thomas, Daniel Lindsey, Kentucky Superstitions Princeton: Princeton University Pross, I920.

Tylor, E. B., Anthropology

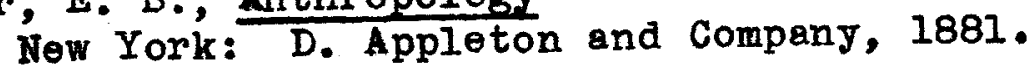


Tylor, E. B., Primitive Culture WeW York: D. AppIeton and Company, 1882.

Weekley, Ernest, Romance of Names

Now York: E. P. Iutton and Company, 1914.

Wells Carolyn, The World's Best Humor

Witham, R. A., Essays of Today

Chicago:' Houghton Mifiln Company, 1931.

Wolford, Leah, The Play Party in Indiana

Indianapolis: Indiana Historical Society, 1916.

Wyman, I., and Brockway, H., Lonesome Tunes, Folksongs from the Kentucky Mountains, 1920. 
B. PUBLICATIONS OF LEARNED ORGANIZATIONS

A Tentative Courge of Study in the Language Arts Amarilio, Texas

Curriculum Bulletin in No. 100, 1937.

Compton's P1ctured Teaching Unit Materials

$C_{h}$ Icago: F. E. Compton and Company, 1933.

Federal Writers' Project - The Creole (French) Ploneers old Post Vincennes.

Federal Writers' Profect in Indiane's Works Progress Administration, 1937. Hoosier Tall Stories. American Gulde Serles.

Hatfield, Wilbur W., An Experience Curriculum in English National Council of Ieachers of English.

Parker, Benjamin S., "Ploneer Life" Indiana Magazine of H1story, vol. 111, Mareh, 1907.

Research Bulletin of the National Education Association. Creating a Curriculum for Adolescent Youth. Vol. VI, Ho. 1 . 